\title{
Structures and Properties of Spherical 90-Vertex Fullerene-Like Nanoballs
}

\author{
Manfred Scheer, ${ }^{[[a]}$ Andrea Schindler, ${ }^{[a]}$ Junfeng Bai, ${ }^{[b]}$ Brian P. Johnson, ${ }^{[a]}$ \\ Roger Merkle, ${ }^{[\mathrm{a}]}$ Rainer Winter, ${ }^{[\mathrm{a}]}$ Alexander V. Virovets, ${ }^{[\mathrm{c}]}$ Eugenia V. Peresypkina, ${ }^{[\mathrm{c}]}$ \\ Vladislav A. Blatov, ${ }^{[\mathrm{d}]}$ Marek Sierka, ${ }^{[\mathrm{e}]}$ and Hellmut Eckert ${ }^{[\mathrm{f}]}$
}

\begin{abstract}
By applying the proper stoichiometry of $1: 2$ to $\left[\mathrm{Cp}^{\mathrm{R}} \mathrm{Fe}\left(\eta^{5}-\mathrm{P}_{5}\right)\right]$ and $\mathrm{CuX}(\mathrm{X}=\mathrm{Cl}, \mathrm{Br})$ and dilution conditions in mixtures of $\mathrm{CH}_{3} \mathrm{CN}$ and solvents like $\mathrm{CH}_{2} \mathrm{Cl}_{2}, 1,2-\mathrm{Cl}_{2} \mathrm{C}_{6} \mathrm{H}_{4}$, toluene, and THF, nine spherical giant molecules having the simplified general formula $\left[\mathrm{Cp}{ }^{\mathrm{R}} \mathrm{Fe}\left(\eta^{5}-\mathrm{P}_{5}\right)\right] @\left[\left\{\mathrm{Cp}^{\mathrm{R}} \mathrm{Fe}\left(\eta^{5}-\mathrm{P}_{5}\right)\right\}_{12^{-}}\right.$ $\left.\{\mathrm{CuX}\}_{25}\left(\mathrm{CH}_{3} \mathrm{CN}\right)_{10}\right] \quad\left(\mathrm{Cp}^{\mathrm{R}}=\eta^{5}-\mathrm{C}_{5} \mathrm{Me}_{5}\right.$ $\left.\left(\mathrm{Cp}^{*}\right) ; \eta^{5}-\mathrm{C}_{5} \mathrm{Me}_{4} \mathrm{Et}\left(\mathrm{Cp}^{\mathrm{Et}}\right) ; \mathrm{X}=\mathrm{Cl}, \mathrm{Br}\right)$ have been synthesized and structurally characterized. The products consist of 90-vertex frameworks consisting of non-carbon atoms and forming fullerene-like structural motifs. Besides the mostly neutral products, some charged
\end{abstract}

derivatives have been isolated. These spherical giant molecules show an outer diameter of $2.24(\mathrm{X}=\mathrm{Cl})$ to $2.26 \mathrm{~nm}(\mathrm{X}=\mathrm{Br})$ and have inner cavities of $1.28(\mathrm{X}=\mathrm{Cl})$ and $1.20 \mathrm{~nm}(\mathrm{X}=$ $\mathrm{Br})$ in size. In most instances the inner voids of these nanoballs encapsulate one molecule of $\left[\mathrm{Cp} * \mathrm{Fe}\left(\eta^{5}-\mathrm{P}_{5}\right)\right]$, which reveals preferred orientations of $\pi-\pi$ stacking between the cyclo- $\mathrm{P}_{S}$ rings of the guest and those of the host mole-

Keywords: copper - host-guest systems - iron - P ligands . self-assembly cules. Moreover, $\pi-\pi$ and $\sigma-\pi$ interactions are also found in the packing motifs of the balls in the crystal lattice. Electrochemical investigations of these soluble molecules reveal one irreversible multi-electron oxidation at $E_{\mathrm{p}}=$ $0.615 \mathrm{~V}$ and two reduction steps $(-1.10$ and $-2.0 \mathrm{~V}$ ), the first of which corresponds to about 12 electrons. Density functional calculations reveal that during oxidation and reduction the electrons are withdrawn or added to the surface of the spherical nanomolecules, and no $\mathrm{Cu}^{2+}$ species are involved.

\section{Introduction}

[a] Prof. Dr. M. Scheer, Dipl.-Chem. A. Schindler, Dr. B. P. Johnson, Dipl--Chem. R. Merkle, Prof. Dr. R. Winter Institut für Anorganische Chemie der Universität Regensburg 93040 Regensburg (Germany)

Fax: $(+49) 941-943-4439$

E-mail: mascheer@chemie.uni-regensburg.de

[b] Dr. J. Bai

Coordination Chemistry Institute \&

the State Key Laboratory of Coordination Chemistry Nanjing University, 210093 Nanjing (China)

[c] Dr. A. V. Virovets, Dr. E. V. Peresypkina

Nikolaev Institute of Inorganic Chemistry, Siberian Division of RAS Acad. Lavrentyev str. 3, Novosibirsk 630090 (Russia)

[d] Prof. Dr. V. A. Blatov Samara State University, Ac. Pavlov str. 1, 443011 Samara (Russia)

[e] Dr. M. Sierka

Institut für Chemie der Humboldt-Universität zu Berlin Unter den Linden 6, 10099 Berlin (Germany)

[f] Prof. Dr. H. Eckert

Institut für Physikalische Chemie der Universität Münster Corrensstrasse 30, 48149 Münster (Germany)
Supramolecular chemistry based on the formation of extended aggregates and networks through noncovalent interactions has produced a large number of spectacular compounds over the years. ${ }^{[1]}$ Within this field large spherical molecules and clusters are of special interest, since they represent an alternative to the established areas of borane cages or the recently developed low-valent aluminium and gallium metalloid clusters. ${ }^{[2]}$ Moreover, the giant chalcogeno-bridged copper and silver clusters ${ }^{[3]}$ and the giant wheelor ball-shaped polyoxomolybdates ${ }^{[4]}$ are the largest structurally characterized clusters so far. By using noncovalent interactions we have developed a synthetic route to large spherical aggregates with nanosized dimensions. ${ }^{[5]}$ This approach is based on $\left[\mathrm{Cp} * \mathrm{Fe}\left(\eta^{5}-\mathrm{P}_{5}\right)\right]$ and $\mathrm{Cu}^{\mathrm{I}}$ halides. By applying special dilution and stoichiometric conditions, the formation of $1 \mathrm{D}$ or $2 \mathrm{D}$ polymers ${ }^{[6]}$ is avoided, and fullerene-like cage compounds of general formula $\left[\left\{\mathrm{Cp} * \mathrm{Fe}\left(\eta^{5}-\mathrm{P}_{5}\right)\right\}_{12}\{\mathrm{CuX}]_{10^{-}}\right.$ $\left.\left\{\mathrm{Cu}_{2} \mathrm{X}_{3}\right\}_{5}\left\{\mathrm{Cu}\left(\mathrm{CH}_{3} \mathrm{CN}\right)_{2}\right\}_{5}\right]^{[7]}$ are exclusively obtained. These nanosized spherical clusters have various remarkable aspects: 1) they consist of 90 non-carbon core atoms and are 
composed of two half shells with fullerene-like topology, 2) despite their high molecular weight they are soluble compounds, and 3) there is evidence that their formation is enhanced by a template effect of an encapsulated molecule of pentaphosphaferrocene. In the following we report on the complete structural characterization of a series of these 90vertex compounds, their solid-state and solution features and their redox properties.

\section{Results and Discussion}

Synthesis and structural characterization in the solid state: Complexes 1-9 were obtained by the reaction of $\left[\mathrm{Cp} * \mathrm{Fe}\left(\eta^{5}-\right.\right.$ $\mathrm{P}_{5}$ )] and $\mathrm{Cu}^{\mathrm{I}}$ halides in mixtures of $\mathrm{CH}_{3} \mathrm{CN}$ with $\mathrm{CH}_{2} \mathrm{Cl}_{2}$, toluene, THF, or 1,2- $\mathrm{C}_{6} \mathrm{H}_{4} \mathrm{Cl}_{2}$ at ambient temperature. To avoid formation of $1 \mathrm{D}$ or $2 \mathrm{D}$ polymers, [CuCl$/ \mathrm{Cp} * \mathrm{Fe}\left(\eta^{5}: \eta^{1}: \eta^{1}-\right.$ $\left.\left.\left.\mathrm{P}_{5}\right)\right\}\right]_{\infty}$ and $\left[\mathrm{CuX}\left[\mathrm{Cp} * \mathrm{Fe}\left(\eta^{5}: \eta^{1}: \eta^{1}: \eta^{1}-\mathrm{P}_{5}\right)\right\}\right]_{\infty}(\mathrm{X}=\mathrm{Br}, \mathrm{I}){ }^{[6]}$ respectively, dilution $(\leq 3.75 \mathrm{~mm})^{[8]}$ and adherence to the correct stoichiometry of $2: 1$ between $\mathrm{CuX}$ and $\left[\mathrm{Cp} * \mathrm{Fe}\left(\eta^{5}-\mathrm{P}_{5}\right)\right]$ are decisive criteria for the exclusive formation of the soluble nanosized products. They are obtained in maximum yields of isolated product of up to $37 \%$. Attempts to obtain soluble products with $\mathrm{CuI}$ failed so far; thus, only spherical 90-vertex molecules containing copper chloride or bromide have been isolated. Attempts to characterise the products by mass spectrometry led only to the observation of fragments and moieties like $\left[\mathrm{Cp} * \mathrm{Fe}\left(\eta^{5}-\mathrm{P}_{5}\right)\right]$ coordinated to some $\mathrm{CuX}$ species. No hemispherical sheet is detected in the gas phase.

The nine isolated spherical compounds, each of which has a unique unit cell, determined by $\mathrm{X}$-ray crystallography (Table 1), are $\mathrm{CuCl}(\mathbf{1}, \mathbf{3 - 5})$ or $\mathrm{CuBr}(\mathbf{2}, \mathbf{6 - 9})$ derivatives containing $\mathrm{Cp}^{*}$ or $\mathrm{Cp}^{\mathrm{Et}}\left(\eta^{5}-\mathrm{C}_{5} \mathrm{Me}_{4} \mathrm{Et}\right.$, compound 2) ligands. They have mixtures of different solvent molecules outside the spherical molecules, which lead to different packing modes. Moreover, they differ in defects in the framework leading to ionic molecules (1 $\mathbf{b}$ and $\mathbf{5}$ ) and the contents of encapsulated pentaphosphaferrocene, which sometimes refined to less than one full molecule per cage $(\mathbf{1}, \mathbf{3}$, and 4$) .^{[9]}$

$\left[\mathrm{Cu}(\mathrm{MeCN})_{4}\right]^{+}\left[\left\{\mathrm{Cp} * \mathrm{Fe}\left(\eta^{5}-\mathrm{P}_{5}\right)\right\}_{0.5} @\left\{\mathrm{Cp} * \mathrm{Fe}\left(\eta^{5}-\mathrm{P}_{5}\right)\right\}_{12}\{\mathrm{CuCl}\}_{25}\right.$ $\left.(\mathrm{MeCN})_{10}\right]_{3}\left[\mathrm{Cp} * \mathrm{Fe}\left(\eta^{5}-\mathrm{P}_{5}\right)\right]_{0.5} @\left[\left\{\mathrm{Cp} * \mathrm{Fe}\left(\eta^{5}-\mathrm{P}_{5}\right)\right\}_{12} \mathrm{Cu}_{24} \mathrm{Cl}_{25}\right.$

$\left.(\mathrm{MeCN})_{8}\right]^{-} \cdot 34 \mathrm{CH}_{2} \mathrm{Cl}_{2}^{[7 \mathrm{a}, 10]} \mathbf{1}$

$\left[\mathrm{Cp} * \mathrm{Fe}\left(\eta^{5}-\mathrm{P}_{5}\right)\right]_{0.5} @\left[\left\{\mathrm{Cp} * \mathrm{Fe}\left(\eta^{5}-\mathrm{P}_{5}\right)\right\}_{12}\{\mathrm{CuCl}\}_{25}(\mathrm{MeCN})_{10}\right]^{\text {7a }} \mathbf{1} \mathbf{a}$

$\left[\mathrm{Cu}(\mathrm{MeCN})_{4}\right]^{+}\left[\left\{\mathrm{Cp} * \mathrm{Fe}\left(\eta^{5}-\mathrm{P}_{5}\right)\right\}_{0.5} @\left\{\mathrm{Cp} * \mathrm{Fe}\left(\eta^{5}-\mathrm{P}_{5}\right)\right\}_{12} \mathrm{Cu}_{24} \mathrm{Cl}_{25}\right.$ $\left.(\mathrm{MeCN})_{8}\right]^{-[7 a]} \mathbf{1 b}$

$\left[\mathrm{Cp}{ }^{\mathrm{Et}} \mathrm{Fe}\left(\eta^{5}-\mathrm{P}_{5}\right)\right] @\left[\left\{\mathrm{Cp} \mathrm{Et}^{\mathrm{Et}} \mathrm{Fe}\left(\eta^{5}-\mathrm{P}_{5}\right)\right\}_{12}\{\mathrm{CuBr}\}_{25}(\mathrm{MeCN})_{10}\right\}$ $.2 \mathrm{CH}_{2} \mathrm{Cl}_{2} \cdot 0.5 \mathrm{MeCN}^{[7 b]} 2$

$\left[\mathrm{Cp} * \mathrm{Fe}\left(\eta^{5}-\mathrm{P}_{5}\right)\right]_{0.5} @\left[\left\{\mathrm{Cp} * \mathrm{Fe}\left(\eta^{5}-\mathrm{P}_{5}\right)\right\}_{12}\{\mathrm{CuCl}\}_{25}(\mathrm{MeCN})_{10}\right]$ $6 \mathrm{CH}_{2} \mathrm{Cl}_{2} \cdot 1.5 \mathrm{MeCN} 3$
$\left[\mathrm{Cp} * \mathrm{Fe}\left(\eta^{5}-\mathrm{P}_{5}\right)\right]_{0.6} @\left[\left\{\mathrm{Cp} * \mathrm{Fe}\left(\eta^{5}-\mathrm{P}_{5}\right)\right\}_{12}\{\mathrm{CuCl}\}_{25}(\mathrm{MeCN})_{10}\right]$ 9.5 THF $2 \mathrm{MeCN} 4$

$\left[\mathrm{Cp} * \mathrm{Fe}\left(\eta^{5}-\mathrm{P}_{5}\right)\right] @\left[\left\{\mathrm{Cp}^{*} \mathrm{Fe}\left(\eta^{5}-\mathrm{P}_{5}\right)\right\}_{12} \mathrm{Cu}_{25} \mathrm{Cl}_{24}(\mathrm{MeCN})_{9}\right]^{+}$
$\left[\left\{\mathrm{Cp} * \mathrm{Fe}\left(\eta^{5}-\mathrm{P}_{5}\right)\right\}_{12} \mathrm{Cu}_{25} \mathrm{Cl}_{26}(\mathrm{MeCN})_{9}\right]^{-} \cdot 12 \mathrm{C}_{7} \mathrm{H}_{8} \cdot 1.5 \mathrm{MeCN} \mathbf{5}$

$\left[\mathrm{Cp} * \mathrm{Fe}\left(\eta^{5}-\mathrm{P}_{5}\right)\right] @\left[\left\{\mathrm{Cp} * \mathrm{Fe}\left(\eta^{5}-\mathrm{P}_{5}\right)\right\}_{12}\{\mathrm{CuBr}\}_{25}(\mathrm{MeCN})_{10}\right]$ $2.9 \mathrm{C}_{6} \mathrm{H}_{4} \mathrm{Cl}_{2} \cdot 3.9 \mathrm{MeCN} 6$

$\left[\mathrm{Cp} * \mathrm{Fe}\left(\eta^{5}-\mathrm{P}_{5}\right)\right] \propto\left[\left\{\mathrm{Cp} * \mathrm{Fe}\left(\eta^{5}-\mathrm{P}_{5}\right)\right\}_{12}\{\mathrm{CuBr}\}_{25}(\mathrm{MeCN})_{10}\right]$ $2.1 \mathrm{C}_{6} \mathrm{H}_{4} \mathrm{Cl}_{2} \cdot \mathrm{MeCN} 7$

$\left[\mathrm{Cp} * \mathrm{Fe}\left(\eta^{5}-\mathrm{P}_{5}\right)\right] @\left[\left\{\mathrm{Cp} * \mathrm{Fe}\left(\eta^{5}-\mathrm{P}_{5}\right)\right\}_{12}\{\mathrm{CuBr}\}_{25}(\mathrm{MeCN})_{10}\right]$ $\cdot 10.4 \mathrm{C}_{7} \mathrm{H}_{8} \cdot 0.8 \mathrm{MeCN} 8$

$\left[\mathrm{Cp} * \mathrm{Fe}\left(\eta^{5}-\mathrm{P}_{5}\right)\right] @\left[\left\{\mathrm{Cp} * \mathrm{Fe}\left(\eta^{5}-\mathrm{P}_{5}\right)\right\}_{12}\{\mathrm{CuBr}\}_{25}(\mathrm{MeCN})_{10}\right]$ $.5 \mathrm{C}_{7} \mathrm{H}_{8} \cdot 17.7 \mathrm{MeCN} 9$

The most frequent and fascinating structure in this series of spherical compounds is that of $\left[\left\{\mathrm{Cp} * \mathrm{Fe}\left(\eta^{5}-\mathrm{P}_{5}\right)\right\}_{12}\{\mathrm{CuX}]_{25}\right.$ $(\mathrm{MeCN})_{10}$ ] (Figure 1). Its structure can be simply described by starting from a single $\left[\mathrm{Cp} * \mathrm{Fe}\left(\eta^{5}-\mathrm{P}_{5}\right)\right]$ fragment. The molecule provides five phosphorus atoms, all of which can coor-
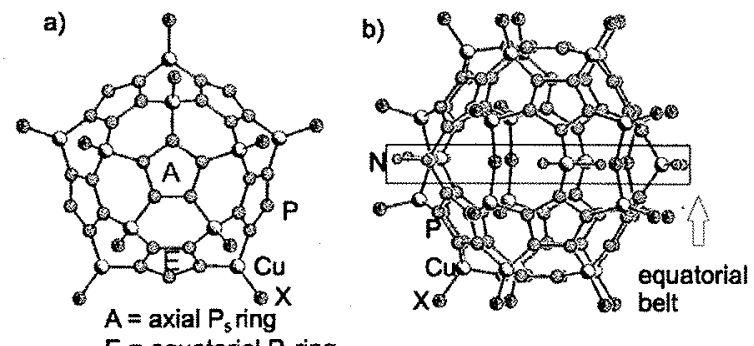

$E=$ equatorial $P_{s}$ ring

c)
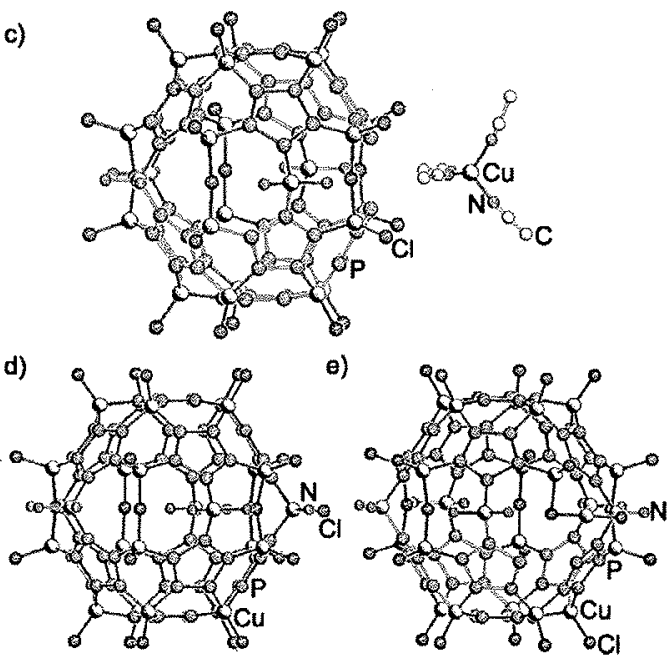

Figure 1. a) Hemisphere exemplified in 3, b) quasi-spherical neutral molecule exemplified in 3, c) ion pair of $\mathbf{1 b}, \mathrm{d}$ ) and e) ion pair in 5. The $\mathrm{Cp}^{*}$ ligands, $\mathrm{Fe}$ atoms and carbon atoms of eight acetonitrile molecules are omitted for clarity. 
Table 1. Crystallographic data and details of X-ray experiments for 3-9

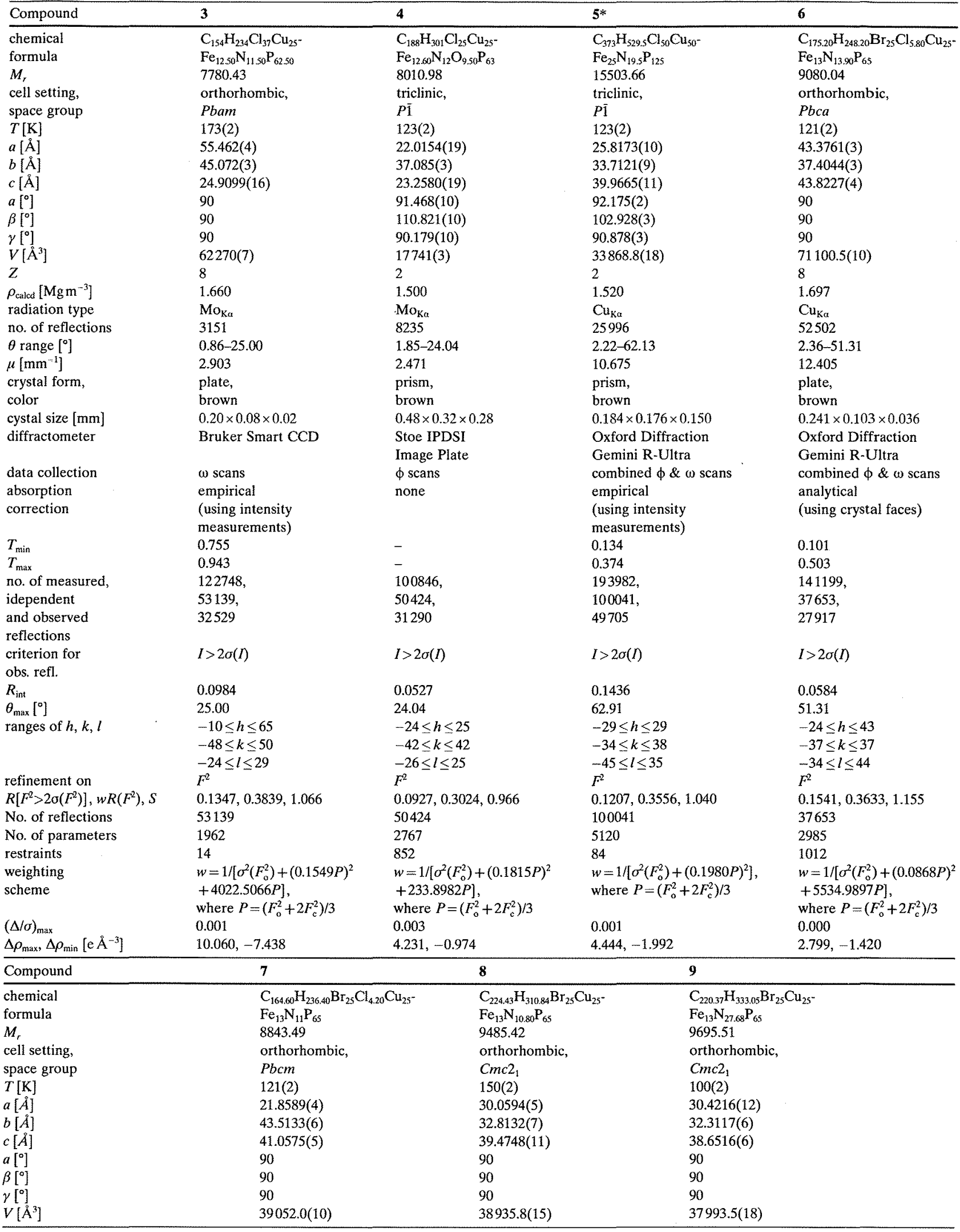


Table 1. (Continued)

\begin{tabular}{|c|c|c|c|}
\hline Compound & 7 & 8 & 9 \\
\hline$Z$ & 4 & 4 & 4 \\
\hline$\rho_{\text {calcd }}\left[\mathrm{Mg} \mathrm{m}^{-3}\right]$ & 1.504 & 1.618 & 1.695 \\
\hline radiation type & $\mathrm{Cu}_{\mathrm{Ka}}$ & $\mathrm{Cu}_{\mathrm{Ka}}$ & $\mathrm{Cu}_{\mathrm{Ka}}$ \\
\hline no. of reflections & 13584 & 19081 & 15306 \\
\hline$\theta$ range [0] & $2.02-56.24$ & $2.29-62.19$ & $3.57-62.25$ \\
\hline$\mu\left[\mathrm{mm}^{-1}\right]$ & 11.175 & 10.995 & 11.294 \\
\hline crystal form, colour & lath-shaped, dark brown & block, brown & block, brown \\
\hline crystal size [mm] & $0.232 \times 0.073 \times 0.005$ & $0.53 \times 0.27 \times 0.19$ & $0.18 \times 0.09 \times 0.09$ \\
\hline \multirow[t]{2}{*}{ diffractometer } & Oxford Diffraction & Oxford Diffraction & Oxford Diffraction \\
\hline & Gemini R-Ultra & Gemini R-Ultra & Gemini R-Uitra \\
\hline data collection & combined $\phi \& \omega$ scans & combined $\phi \& \omega$ scans & combined $\phi \& \omega$ scans \\
\hline absorption & empirical & analytical & empirical \\
\hline correction & $\begin{array}{l}\text { (using intensity } \\
\text { measurements) }\end{array}$ & (using crystal faces) & $\begin{array}{l}\text { (using intensity } \\
\text { measurements) }\end{array}$ \\
\hline$T_{\min }$ & 0.143 & 0.029 & 0.552 \\
\hline$T_{\max }$ & 0.669 & 0.155 & 1 \\
\hline no. of measured, & 82402 & 41469 & 42905 \\
\hline independent & 24453 & 22182 & 24948 \\
\hline and observed reflections & 9432 & 18858 & 19813 \\
\hline criterion for observed reflections & $I>2 \sigma(l)$ & $I>2 \sigma(l)$ & $I>2 \sigma(I)$ \\
\hline$R_{\text {int }}$ & 0.1254 & 0.1063 & 0.0451 \\
\hline$\theta_{\max }\left[{ }^{\circ}\right]$ & 56.24 & 62.19 & 62.25 \\
\hline \multirow[t]{3}{*}{ ranges of $h, k, l$} & $-23 \leq h \leq 22$ & $-34 \leq h \leq 32$ & $-17 \leq h \leq 34$ \\
\hline & $-35 \leq k \leq 46$ & $-37 \leq k \leq 19$ & $-28 \leq k \leq 36$ \\
\hline & $-43 \leq l \leq 41$ & $-39 \leq l \leq 44$ & $-44 \leq l \leq 42$ \\
\hline refinement on & $F^{2}--1$ & $F^{2}---$ & $F^{2}$ \\
\hline$R\left[F^{2}>2 \sigma\left(F^{2}\right)\right], w R\left(F^{2}\right), S$ & $0.1255,0.4126,1.121$ & $0.0986,0.2688,1.038$ & $0.0488,0.1266,1.015$ \\
\hline no. of reflections & 24453 & 22182 & 24948 \\
\hline no. of parameters & 1392 & 1499 & 1720 \\
\hline restraints & 518 & 103 & 118 \\
\hline weighting & $w=1 /\left[\sigma^{2}\left(F_{o}^{2}\right)+(0.2000 P)^{2}\right]$ & $w=1 /\left[\sigma^{2}\left(F_{0}^{2}\right)+(0.1677 P)^{2}\right.$ & $w=1 /\left[\sigma^{2}\left(F_{\mathrm{o}}^{2}\right)+(0.0687 P)^{2}\right]$ \\
\hline scheme & where $P=\left(F_{\mathrm{o}}^{2}+2 F_{\mathrm{c}}^{2}\right) / 3$ & $\begin{array}{l}+1161.8551 P] \\
\text { where } P=\left(F_{\mathrm{o}}^{2}+2 F_{\mathrm{c}}^{2}\right) / 3\end{array}$ & where $P=\left(F_{\mathrm{o}}^{2}+2 F_{\mathrm{o}}^{2}\right) / 3$ \\
\hline$(\Delta / \sigma)_{\max }$ & 0.002 & 0.000 & 0.000 \\
\hline$\Delta \rho_{\max }, \Delta \rho_{\min }\left[\mathrm{e} \AA^{3}\right]$ & $3.016,-1.179$ & $1.694,-1.449$ & $1.828,-0.785$ \\
\hline Flack parameter & - & $0.077(10)$ & $0.016(5)$ \\
\hline
\end{tabular}

*Accompanied by $\mathrm{C}_{2} \mathrm{~B}_{10} \mathrm{H}_{12} @\left[\left[\mathrm{CP} * \mathrm{Fe}\left(\eta^{5}-\mathrm{P}_{5}\right)\right\}_{12}(\mathrm{CuCl})_{20}\right] .^{[14]}$

dinate to a $\mathrm{CuX}$ fragment. Moreover, the copper atoms are coordinated by five more $\left[\mathrm{Cp} * \mathrm{Fe}\left(\eta^{5}-\mathbf{P}_{5}\right)\right]$ molecules, so that the $\mathrm{Cu}$ atoms are coordinated by three $\mathrm{P}_{5}$ rings each. The coordination sphere of the copper atoms is completed by one halogenide atom $\mathrm{X}(\mathrm{X}=\mathrm{Cl}, \mathrm{Br})$. These five $\mathrm{P}_{5}$ rings are arranged uniformly around the central one. The resulting $\left[\{\mathrm{CuX}\}_{10}\left[\mathrm{Cp} * \mathrm{Fe}\left(\eta^{5}-\mathrm{P}_{5}\right)\right\}_{6}\right]$ fragment is hemispherical. Its curvature is dictated by the tetrahedral coordination of each $\mathrm{Cu}^{\mathrm{I}}$ ion. This fragment is in the following denoted 40-vertex shell, due to the thirty phosphorus and ten copper atoms it comprises (Figure $1 \mathrm{a}$ ). This 40 -vertex shell consists of six conjugated $\mathrm{P}_{5}$ rings and ten $\mathrm{Cu}_{2} \mathrm{P}_{4}$ six-membered rings. Hence, the ideal point group of the 40 -vertex shell, $C_{5 n}$ originates from the initial central pentagonal phosphorus ring of the $\left[\mathrm{Cp} * \mathrm{Fe}\left(\eta^{5}-\mathrm{P}_{5}\right)\right]$ molecule. At the edge each 40 -vertex shell has five phosphorus atoms and five copper atoms available for further coordination.

In the present cases two 40 -vertex shells are joined by ten additional bridges: five $\mathrm{X}^{-}$ions between the $\mathrm{Cu}$ atoms of the shells and five $\left[\mathrm{Cu}(\mathrm{NCMe})_{2}\right]^{+}$bridging fragments con- joining the $\mathrm{P}$ atoms of the shells. The resulting quasi-spherical molecule of $D_{5 h}$ point symmetry has a total of 90 vertices; 80 are in the two shells, while an additional five $\mu$-Cu$(\mathrm{NCMe})_{2}{ }^{+}$and five $\mu-\mathrm{X}$ give $\left[\left\{\mathrm{Cp} * \mathrm{Fe}\left(\eta^{5}-\mathrm{P}_{5}\right)\right\}_{12}\{\mathrm{CuX}\}_{25}\right.$ $(\mathrm{MeCN})_{10}$ ] (Figure 1b). Between the shells there is an "equatorial belt" of ten eight-membered $\mathrm{Cu}_{3} \mathrm{P}_{4} \mathrm{X}$ rings. The face symbol ${ }^{[11]}$ for the $\{\mathrm{Cu}, \mathrm{P}, \mu-\mathrm{X}\}$ cage is $\left[5^{12} \cdot 6^{20} \cdot 8^{10}\right]$. The plane of the "belt" and the direction of the pseudo-fivefold axis can naturally be called equatorial and axial, respectively. ${ }^{[12]}$ In the 90-vertex moiety the shells of $C_{5 v}$ symmetry are related to each other by mirror plane resulting an idealized $D_{5 h}$ point group.

In some cases other structurally related molecules were observed. A $\left[\mathrm{Cu}_{24} \mathrm{Cl}_{25}\left\{\mathrm{Cp} * \mathrm{Fe}\left(\eta^{5}-\mathrm{P}_{5}\right)\right\}_{12}(\mathrm{MeCN})_{8}\right]^{-}$anion (Figure $1 \mathrm{c})$ co-crystallized together with the usual 90-vertex molecule in 1 . This anion was treated as the result of dissociation of one $\left\{\mathrm{Cu}(\mathrm{NCMe})_{2}\right\}^{+}$fragment from the equatorial belt of the usual 90 -vertex molecule, ${ }^{[7 \mathrm{a}]}$ where one of the equatorial $\mathrm{Cu}(\mathrm{NCMe})_{2}$ fragments is absent. In the crystal structure this anion is accompanied by a $\left[\mathrm{Cu}(\mathrm{NCMe})_{4}\right]^{+}$ 
cation in an ion pair. This example may illustrate chemical lability of the 90 -vertex molecule and its potential as the basis for forming other large oligomeric complexes.

Another variation of the usual 90-vertex motif is the formation of two charged quasi-spherical moieties, namely, cation $\left[\left\{\mathrm{Cp} * \mathrm{Fe}\left(\eta^{5}-\mathrm{P}_{5}\right)\right\}_{12} \mathrm{Cu}_{25} \mathrm{Cl}_{24}(\mathrm{MeCN})_{9}\right]^{+}$and anion $\left[\left[\mathrm{Cp} * \mathrm{Fe}\left(\eta^{5}-\mathrm{P}_{5}\right)\right\}_{12} \mathrm{Cu}_{25} \mathrm{Cl}_{26}(\mathrm{MeCN})_{9}\right]^{-}$, found in $\mathbf{5}$. The anion displays the usual 90-vertex structure with one of the terminal $\mathrm{MeCN}$ molecules replaced by $\mathrm{Cl}^{-}$(Figure $1 \mathrm{~d}$ ). In the molecular structure of the cation the equatorial belt is disturbed by the lack of a $\mathrm{Cu}-\mathrm{P}$ bond (Figure $1 \mathrm{e}$ ). The $\mathrm{Cu}-$ $\mathrm{Cl}_{\text {term }}$ fragment "migrates" within the equatorial belt towards the nearest $\mathrm{Cu}(\mathrm{MeCN})_{2}$ fragment, where $\mathrm{Cl}_{\text {term }}$ replaces one of $\mathrm{MeCN}$ ligands and becomes a bridge (Figure 2).

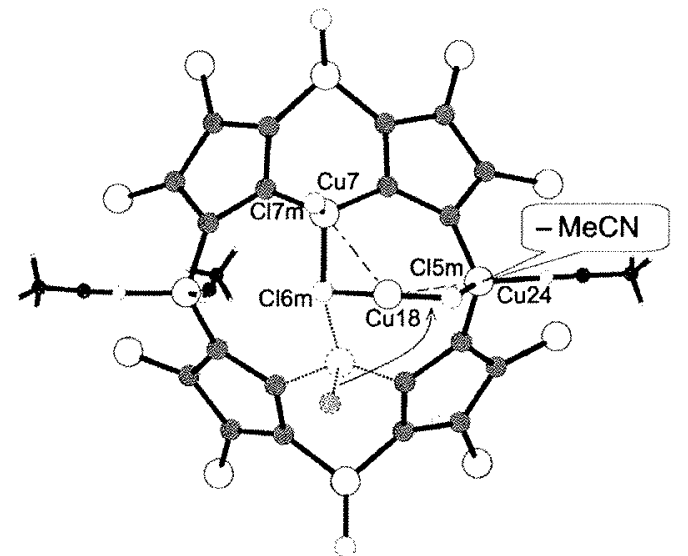

Figure 2. Fragment of $\left[\left[\mathrm{Cp} F \mathrm{Fe}\left(\eta^{5}-\mathrm{P}_{5}\right)\right\} \mathrm{Cu}_{25} \mathrm{Cl}_{24}(\mathrm{MeCN})_{9}\right]^{+}$cation of 5 and of neutral quasi-spherical molecule (short $\mathrm{Cu} \cdots \mathrm{Cu}$ contacts are shown as dashed lines). The "migrating" pair of atoms (Cu18-Cl5m), indicated by an arrow, displaces an acetonitrile molecule. Selected distances [ $\AA]$ and

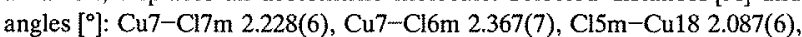
$\mathrm{Cl6m} \mathrm{Cu} 18$ 2.092(6), Cu24-Cl5m 2.333(5), Cu24-Cu18 3.020(4), Cu7Cu18 3.097(4); Cl7m-Cu7-Cl6m 108.8(2), Cl5m-Cu18-Cl6m 177.5(3), $\mathrm{Cu} 18-\mathrm{Cl} 5 \mathrm{~m}-\mathrm{Cu} 2486.0(2)$, Cu18-Cl6m-Cu7 87.8(2).

In addition, one of chloride anions is equally disordered over a terminal and a bridging position. Thus, two isomeric cations, one with $\mathrm{Cl}_{\text {term }}$, and another with $\mathrm{Cl}_{\text {bridge }}$, are perfectly overlapped in the crystal structure. Having 25 copper and 24 chlorine atoms, each moiety bears a positive charge. The unusual $\mathrm{Cu}_{3} \mathrm{Cl}_{2}$ fragment is probably stabilized by $\mathrm{Cu} \cdots \mathrm{Cu}$ interactions; the distances are 3.020(4) and 3.097(4) $\AA$. These interactions are most probably the reason for the non-typical $\mathrm{Cu}-\mathrm{Cl}-\mathrm{Cu}$ angles of less than $90^{\circ}(86.0$ and $87.7^{\circ}$ ). A similar fragment was found in the trinuclear mixed-valent complex bis[( $\mu$-chloro)-chloro-(1-cyclopropyl6-fluoro-1,4-dihydro-4-oxo-7-piperazin-1-ylquinoline-3-carboxylate- $\left.\left.\mathrm{O}, \mathrm{O}^{\prime}\right)\right]$ tricopper(I,I,II)], ${ }^{[13]}$ where the exceptionally small $\mathrm{Cu}^{2+}-\mu-\mathrm{Cl}^{-}-\mathrm{Cu}^{+}$angle of $84.4^{\circ}$ is forced by shortened $\mathrm{Cu}^{2+} \ldots \mathrm{Cu}^{+}$and $\mathrm{Cu}^{+} \ldots \mathrm{O}$ distances $(3.39$ and $2.88 \AA$, respectively).

By a different combination of the two 40 -vertex shells another spherical moiety that differs from the described 90 - vertex system in compounds 1-9 can be formed. Thus, two shells that are functionally complementary were also found to join directly. The copper atoms of one shell are coordinated by the $\mathrm{P}$ atoms of the other. The resulting 80 -vertex molecule $\left[\left\{\mathrm{Cp} * \mathrm{Fe}\left(\eta^{5}-\mathrm{P}_{5}\right)\right\}_{12}\{\mathrm{CuX}\}_{20}\right]$ has pseudo-icosahedral symmetry and can incorporate $1,2-\mathrm{C}_{2} \mathrm{~B}_{10} \mathrm{H}_{12}{ }^{[14]}$ The face symbol for the $\{\mathrm{Cu}, \mathrm{P}\}$ cage is $\left[5^{12}, 6^{30}\right]$. In this case axial and equatorial directions are indistinguishable. In the 80-vertex structure they are related by a $\overline{5}$ inversion axis to give point group $I_{h}$. Interestingly the 90 - and 80 -vertex moieties can be the products of the same reaction, just like $\mathrm{C}_{2} \mathrm{~B}_{10} \mathrm{H}_{12} @$ $\left[\left\{\mathrm{Cp} * \mathrm{Fe}\left(\eta^{5}-\mathrm{P}_{5}\right)\right\}_{12}[\mathrm{CuCl}\}_{20}\right]^{[14]}$ and compound $\mathbf{5}$. It is noteworthy that both cages are unknown in porous zeolite-like materials. ${ }^{[15]}$

Bond lengths and angles: The geometrical characteristics of the quasi-spherical core in compounds 1-9 are reproducible. The average of $\mathrm{Cu}-\mathrm{P}, \mathrm{Cu}-\mathrm{N}$, and $\mathrm{P}-\mathrm{P}$ bond lengths vary in narrow ranges of $2.29-2.31,1.98-2.00$, and $2.10-2.11 \AA$, respectively, while the average $\mathrm{P}-\mathrm{Cu}-\mathrm{P}$ angles are constant within about $3^{\circ}$ (Table 2$)$. $\left[\mathrm{Cp}^{\mathrm{R}} \mathrm{Fe}\left(\eta^{5}-\mathrm{P}_{5}\right)\right]\left(\mathrm{Cp}^{\mathrm{R}}=\right.$ any cyclopentadienyl ligand) can coordinate a metal atom in an $\eta^{1}$ or $\eta^{2}$ way. Analysis of CSD data ${ }^{[16]}$ (14 $\mathrm{P}_{5}$-containing compounds) and our data shows that $\mathrm{P}-\mathrm{P}$ bond lengths are almost unaffected in the case of $\eta^{1}$ coordination. The $\mathrm{P}-\mathrm{P}$ distances in compounds 1-9 (Table 2) are in good agreement with both the $\mathrm{P}-\mathrm{P}$ bond range of $2.05-2.16 \AA$ (av $2.10 \AA$ for CSD data) and with the $\mathrm{P}-\mathrm{P}$ bond range of $2.11-2.12 \AA$ (av $2.11 \AA$ ) in the crystal structure of non-coordinated [Cp*Fe$\left.\left(\eta^{5}-\mathrm{P}_{5}\right)\right] \cdot{ }^{[17,18]}$ In the case of $\eta^{2}$ coordination the formation of sterically strained $\mathrm{P}_{2} \mathrm{M}$ rings elongates the $\mathrm{P}-\mathrm{P}$ bonds significantly up to approximately $2.35 \AA$.

The terminal $\mathrm{Cu}-\mathrm{X}$ bonds vary little within the $\mathrm{CuCl}-$ and CuBr-containing clusters and range from 2.22 to 2.23 for $\mathrm{X}=\mathrm{Cl}$ and from 2.35 to $2.37 \AA$ for $\mathrm{X}=\mathrm{Br}$. Some variations are related to different bridging $X$ atoms. In accordance with the elongation of $\mathrm{Cu}-\mathrm{X}_{\text {bridge }}$ distances on going from $\mathrm{X}=\mathrm{Cl}(2.31-2.35 \AA)$ to $\mathrm{X}=\mathrm{Br}(2.35-2.47 \AA)$ the $\mathrm{Cu}-\mathrm{X}_{\text {bridge }}{ }^{-}$ $\mathrm{Cu}$ angles systematically decrease from $160-166^{\circ}$ to 147 $154^{\circ}$, respectively. Thus, the equatorial belt is the most flexible part of the quasi-spherical core.

Outer radius: ${ }^{[19]}$ Irrespective of the structural variations the quasi-spherical core of the 90 -vertex clusters based on the $\left[\mathrm{Cp} * \mathrm{Fe}\left(\eta^{5}-\mathrm{P}_{5}\right)\right]$ moiety have slightly different axial and equatorial dimensions (Table $1 S$ in Supporting Information). The axial radii $\left(R_{\mathrm{ax}}\right)$ are usually longer than the equatorial ones $\left(R_{\mathrm{cq}}\right)$. On going from $\mathrm{X}=\mathrm{Cl}$ to $\mathrm{Br}$, the values of $R_{\mathrm{ax}}$ (11.1$11.3 \AA$ ) vary less than those of $R_{\mathrm{eq}}(10.8-11.2$ and $10.7-$ $11.1 \AA$, respectively). Nevertheless, bromo derivatives have systematically smaller equatorial radii and hence deviate more from a "spherical shape" than chloro ones (Table 1S in Supporting Information). The most "spherical" is the anion in $\mathbf{1 b}$ with $R_{\mathrm{ax}}=R_{\mathrm{eq}}$, while the most distorted is the neutral molecule in 6 . One could expect bigger size differences between chloro and bromo derivatives. However, the reason lies in the geometric characteristics of the equatorial 
Table 2. Selected bond lengths $[\AA]$ and angles $\left[^{\circ}\right]$ (min.-max., av.) in $\left[\left\{\mathrm{Cp} * \mathrm{Fe}\left(\eta^{5}-\mathrm{P}_{5}\right)\right\}_{12}[\mathrm{CuX}]_{25}(\mathrm{MeCN})_{10}\right]$ and related moieties for 1-9.

\begin{tabular}{|c|c|c|c|c|c|c|c|c|c|}
\hline Compound & $\mathbf{1}, \mathrm{X}=\mathrm{Cl}$ & $2, \mathrm{X}=\mathrm{Br}$ & $3, \mathrm{X}=\mathrm{Cl}$ & $4, X=C l$ & $5, \mathrm{X}=\mathrm{Cl}$ & $6, X=B r$ & $7, X=B r$ & $8, X=B r$ & $9, X=B r$ \\
\hline $\mathrm{Cu}-\mathrm{P}$ & $\begin{array}{l}2.217(8)- \\
2.317(5) \\
2.290\end{array}$ & $\begin{array}{l}2.284(4)- \\
2.324(7) \\
2.304\end{array}$ & $\begin{array}{l}2.264(5)- \\
2.353(7) \\
2.291\end{array}$ & $\begin{array}{l}2.282(4)- \\
2.317(4) \\
2.305\end{array}$ & $\begin{array}{l}2.255(5)- \\
2.332(6) \\
2.293\end{array}$ & $\begin{array}{l}2.274(11)- \\
2.328(10) \\
2.301\end{array}$ & $\begin{array}{l}2.263(8)- \\
2.331(13) \\
2.299\end{array}$ & $\begin{array}{l}2.280(5)- \\
2.316(7) \\
2.302\end{array}$ & $\begin{array}{l}2.283(3)- \\
2.353(2) \\
2.302\end{array}$ \\
\hline $\mathrm{Cu}-\mathrm{X}_{\mathrm{term}}$ & $\begin{array}{l}2.186(4) \\
2.254(6) \\
2.216\end{array}$ & $\begin{array}{l}2.328(3)- \\
2.379(3) \\
2.351\end{array}$ & $\begin{array}{l}2.190(8) \\
2.256(6) \\
2.221\end{array}$ & $\begin{array}{l}2.218(4)- \\
2.258(4) \\
2.234\end{array}$ & $\begin{array}{l}2.193(6)- \\
2.256(5) \\
2.221\end{array}$ & $\begin{array}{l}2.448(5)- \\
2.478(6) \\
2.463\end{array}$ & $\begin{array}{l}2.331(7)- \\
2.366(5) \\
2.348\end{array}$ & $\begin{array}{l}2.334(4)- \\
2.454(5) \\
2.363\end{array}$ & $\begin{array}{l}2.341(2)- \\
2.470(2) \\
2.366\end{array}$ \\
\hline $\mathrm{Cu}-\mathrm{X}_{\text {bridge }}$ & $\begin{array}{l}2.291(6)- \\
2.356(5) \\
2.324\end{array}$ & $\begin{array}{l}2.446(3)- \\
2.472(4) \\
2.462\end{array}$ & $\begin{array}{l}2.282(9)- \\
2.372(6) \\
2.327\end{array}$ & $\begin{array}{l}2.337(5)- \\
2.353(5) \\
2.348\end{array}$ & $\begin{array}{l}2.228(6) \\
2.367(7) \\
2.313\end{array}$ & $\begin{array}{l}2.327(6)- \\
2 ., 472(7) \\
2.355\end{array}$ & $\begin{array}{l}2.436(7)- \\
2.476(5) \\
2.463\end{array}$ & $\begin{array}{l}2.466(4)- \\
2.477(4) \\
2.471\end{array}$ & $\begin{array}{l}2.453(2)- \\
2.474(2) \\
2.465\end{array}$ \\
\hline $\mathrm{Cu}-\mathrm{N}_{\mathrm{MeCN}}$ & $\begin{array}{l}1.84(3)- \\
2.176(18) \\
1.988\end{array}$ & $\begin{array}{l}1.916(18)- \\
2.024(18) \\
1.981\end{array}$ & $\begin{array}{l}1.967(17)- \\
2.44(2) \\
2.061\end{array}$ & $\begin{array}{l}1.951(15)- \\
2.002(18) \\
1.979\end{array}$ & $\begin{array}{l}1.925(17) \\
2.05(2) \\
1.978\end{array}$ & $\begin{array}{l}1.93(4)- \\
2.06(4) \\
2.00\end{array}$ & $\begin{array}{l}1.96(2)- \\
2.10(2) \\
2.00\end{array}$ & $\begin{array}{l}1.96(3)- \\
2.044(19) \\
2.001\end{array}$ & $\begin{array}{l}1.974(11)- \\
1.988(10) \\
1.982\end{array}$ \\
\hline $\mathrm{P}-\mathrm{P}$ & $\begin{array}{l}2.093(6)- \\
2.116(6) \\
2.096\end{array}$ & $\begin{array}{l}2.075(8)- \\
2.130(5) \\
2.102\end{array}$ & $\begin{array}{l}2.086(8)- \\
2.116(7) \\
2.101\end{array}$ & $\begin{array}{l}2.095(5)- \\
2.129(6) \\
2.113\end{array}$ & $\begin{array}{l}2.077(8)- \\
2.127(7) \\
2.103\end{array}$ & $\begin{array}{l}2.063(14)- \\
2.129(12) \\
2.101\end{array}$ & $\begin{array}{l}2.085(10)- \\
2.159(9) \\
2.109\end{array}$ & $\begin{array}{l}2.078(7)- \\
2.125(8) \\
2.106\end{array}$ & $\begin{array}{l}2.090(4)- \\
2.120(4) \\
2.105\end{array}$ \\
\hline P-Cu-P & $\begin{array}{l}96.58(17)- \\
111.04(19) \\
100.85\end{array}$ & $\begin{array}{l}97.3(2)- \\
117.57(14) \\
102.08\end{array}$ & $\begin{array}{l}95.9(2)- \\
112.5(3) \\
101.2\end{array}$ & $\begin{array}{l}97.25(14)- \\
111.60(15) \\
100.37\end{array}$ & $\begin{array}{l}96.6(2)- \\
112.98(19), \\
100.41\end{array}$ & $\begin{array}{l}97.9(3)- \\
116.0(3) \\
101.5\end{array}$ & $\begin{array}{l}97.7(4)- \\
119.3(3) \\
102.6\end{array}$ & $\begin{array}{l}97.4(3)- \\
115.2(2) \\
101.4\end{array}$ & $\begin{array}{l}97.82(12)- \\
114.77(18) \\
101.68\end{array}$ \\
\hline $\mathrm{Cu}-\mathrm{X}_{\text {bridge }} \cdot \mathrm{Cu}$ & $\begin{array}{l}152.1(4)- \\
168.3(3) \\
163.1 \\
{[7 a]}\end{array}$ & $\begin{array}{l}143.56(12)- \\
160.2(2), \\
154.11 \\
{[76]}\end{array}$ & $\begin{array}{l}147.8(7)- \\
171.2(3) \\
160.4 \\
\text { this work }\end{array}$ & $\begin{array}{l}163.5(2)- \\
166.8(2) \\
165.9 \\
\text { this work }\end{array}$ & $\begin{array}{l}156.9(4)- \\
169.4(3) \\
164.6 \\
\text { this work }\end{array}$ & $\begin{array}{l}142.0(3)- \\
150.16(19), \\
147.29 \\
\text { this work }\end{array}$ & $\begin{array}{l}141.8(2)- \\
151.8(2) \\
147.98 \\
\text { this work }\end{array}$ & $\begin{array}{l}148.81(15)- \\
152.77(16) \text {, } \\
150.59 \\
\text { this work }\end{array}$ & $\begin{array}{l}149.68(8)- \\
151.61(12) \\
150.65 \\
\text { this work }\end{array}$ \\
\hline
\end{tabular}

belt, which are different in the two cases. In the bromo derivatives, the effect of elongated $\mathrm{Cu}-\mathrm{Br}_{\text {bridge }}$ bonds is compensated by a decrease in the $\mathrm{Cu}-\mathrm{Br}_{\text {bridgc }}-\mathrm{Cu}$ angles. In the chloro derivatives the corresponding bonds are shorter, but the angles are more obtuse (Table 2).

The encapsulated $\left[\mathrm{Cp} * \mathrm{Fe}\left(\eta^{5}-\mathbf{P}_{5}\right)\right]$ molecule and the inner radius of the host moiety: Independent of its charge, every 90-vertex moiety encapsulates statistically one molecule of $\left[\mathrm{Cp} * \mathrm{Fe}\left(\eta^{5}-\mathrm{P}_{5}\right)\right]$ (or $\left[\mathrm{Cp}^{\mathrm{Et}} \mathrm{Fe}\left(\eta^{5}-\mathrm{P}_{5}\right)\right] \mathrm{Cp}^{\mathrm{Et}}=\left(\eta^{5}-\mathrm{C}_{5} \mathrm{Me}_{4} \mathrm{Et}\right)$ in 2$)$, which can be either ordered (in 1 and 5 ) or disordered, typically over two (in 1-3, 6-9) or even three (in 4) positions (Figure $3 \mathrm{a}$ and $\mathrm{b}$ ). The orientations of the disordered molecule look quite arbitrary on first sight. However, in all disordered positions the $\left[\mathrm{Cp} * \mathrm{Fe}\left(\eta^{5}-\mathrm{P}_{5}\right)\right]$ molecules are always oriented with the $P_{5}$ ring pointing towards an internal $P_{5}$ ring of the spherical moiety, while the encapsulated $\left[\mathrm{Cp}^{\mathrm{Et}} \mathrm{Fe}\left(\eta^{5}\right.\right.$ $\left.P_{5}\right)$ ] is oriented randomly due to the more bulky unsymmetrical ethyl substituent on the cyclopentadienyl ligand. More-
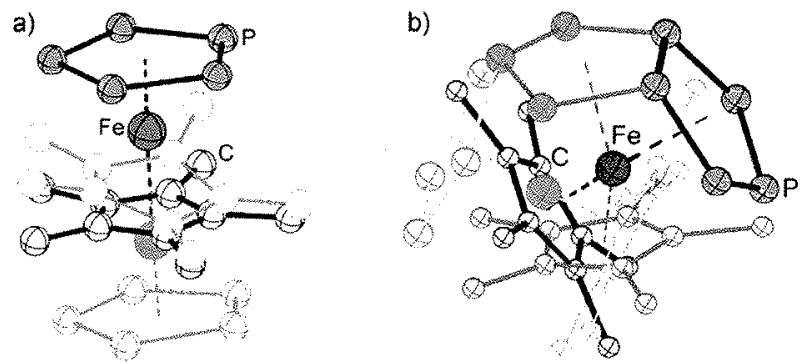

Figure 3. Typical disorder of encapsulated $\left[\mathrm{Cp} * \mathrm{Fe}\left(\eta^{5}-\mathrm{P}_{5}\right)\right]$ molecule a) over two (in 8) and $b$ ) three positions (in 4). Major position with occupancy factor 0.78 is shown dark in a). Different positions of the same probability (0.2) are shown by different colours in b). over, only two types of preferred orientations for $[\mathrm{Cp} * \mathrm{Fe}$ $\left.\left(\eta^{5}-P_{5}\right)\right]$ with respect to the $P_{5} \cdots P_{5}$ orientation are observed, which are termed "axial" and "equatorial" in reference to whether the $P_{5}$ ring of the encapsulated molecule interacts with the central $P_{5}$ ring or one of the five equivalent $P_{5}$ rings at the rim of a hemispherical fragment (Figure $1 \mathrm{a}$ ). The $\mathrm{P}_{5} \cdots \mathrm{P}_{5}$ rings of host and guest molecules inevitably adopt an eclipsed conformation, and are remarkably parallel to one another (the interplanar angle $\phi$ is less than $3.5^{\circ}$, Table $1 \mathrm{~S}$ in Supporting Information), with quite short dot-to-plane distances of $3.77-4.03 \AA$. These contacts are possibly due to weak $\pi-\pi$ interactions between the cyclo- $\mathrm{P}_{5}$ ligands (Figure 4). The shortest P...P contacts of 3.53-3.77 $\AA\left(d_{\min }\right.$, Table $1 \mathrm{~S}$ in the Supporting Information) in 1-9 are close to twice the van der Waals radius of phosphorus $(3.6 \AA) .{ }^{[20]}$

No other examples of such interactions in cyclo- $\mathrm{P}_{5}$-containing compounds are known. ${ }^{[16]}$ The cyclo- $\mathrm{P}_{5}$ ligands are always eclipsed from non-covalent interactions in both oligomeric and polymeric structures. Only two ${ }^{[17,21]}$ stacking in-
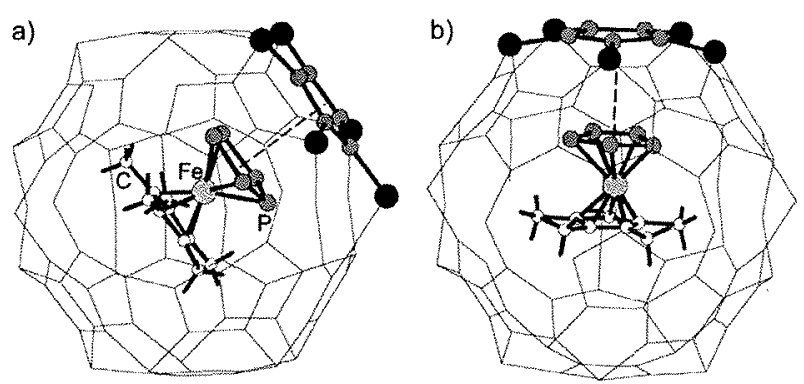

Figure 4. Face-to-face $P_{5} \ldots P_{5}$ stacking interactions (dashed lines) a) with equatorial $(3.911 \AA)$ and b) axial orientation $(3.999 \AA)$ of guest $\left[\mathrm{C} \mathrm{p}^{* \mathrm{Fe}}\right.$ $\left.\left(\eta^{5}-P_{5}\right)\right]$ molecule in structure of 5 . 
teractions involving the cyclo- $\mathrm{P}_{5}$ ring have been found, both of which feature $\mathrm{Cp} \cdots \mathrm{P}_{5}$ slipped stacking with dot-to-plane distances of 3.680 and $3.903 \AA$ and $\phi$ values of 7.0 and $0.7^{\circ}$ in $\left[\mathrm{Cp} * \mathrm{Fe}\left(\eta^{5}-\mathrm{P}_{5}\right)\right]^{[17]}$ and $\left[\mathrm{Cp}{ }^{\mathrm{Et}} \mathrm{Os}\left(\eta^{5}-\mathrm{P}_{5}\right)\right],{ }^{[21]}$ respectively. It is probably the unique spherical shape of $\left[\left\{\mathrm{Cp} * \mathrm{Fe}\left(\eta^{5}-\mathrm{P}_{5}\right)\right\}_{12^{-}}\right.$ $\left.\{\mathrm{CuX}\}_{25}(\mathrm{MeCN})_{10}\right]$ and related moieties which promotes these interactions. Although both $\mathrm{P}_{5} \cdots \mathrm{P}_{5}$ and $\mathrm{Cp} \cdots \mathrm{P}_{5}$ interactions are generally possible, the $\left[\mathrm{Cp} * \mathrm{Fe}\left(\eta^{5}-\mathrm{P}_{5}\right)\right]$ guest molecule is unable to approach the $\mathbf{P}_{5}$ rings of the curved inner surface of the host molecule through the $\mathrm{Cp}^{*}$ fragment for steric reasons. Thus, the observed $\mathrm{P}_{5} \cdots \mathrm{P}_{5}$ interactions can be rationalized as enforced $\pi$ stacking.

The inner cavity of the quasi-spherical moieties is non-isometric, like the outer one (Table $1 \mathrm{~S}$ in Supporting Information). However, in contrast to the outer radii, the inner equatorial radius $\left(r_{\mathrm{eq}}\right)$ is larger than the axial $\left(r_{\mathrm{ax}}\right)$ one, irrespective of the nature of X. The value of $r_{\mathrm{eq}}$ varies between 6.0 and $6.4 \AA$ for $\mathrm{X}=\mathrm{Cl}$, and between 5.8 and $6.0 \AA$ for $\mathrm{X}=$ $\mathrm{Br}$. The $r_{\mathrm{ax}}$ value is less affected by the nature of $\mathrm{X}$, with values of about $6.3-6.5 \AA$ for chloro and $6.6 \AA$ for bromo derivatives. In other words, on going from $\mathrm{X}=\mathrm{Cl}$ to $\mathrm{Br}$ the cavity elongates in the axial and contracts in the equatorial direction of the moiety. The guest molecules always occupy the axial position for bromide-containing hosts; this correlates with elongation of the inner cavity in axial directions. Chloride-containing hosts, however, have more isometric cavities and accommodate both orientations of their guests (Table 1S in Supporting Information). For chloride-containing hosts, the axial orientation of guests corresponds to larger average distortions of the cavity than the equatorial one. Either a "guest effect" or the nature of the halogen atom or both in compromise may cause these differences.

Intermolecular interactions between spherical moieties: Bearing in mind experimental uncertainty and incomplete localization of solvent molecules in the X-ray structural analysis, some features of intermolecular bonding in 1-9 are analyzed in the following. The interactions are important with a view to influencing the packing motif of the large spherical moieties. Thorough analysis showed two types of intermolecular bonding, namely, $\pi-\pi$ interactions between $C \mathrm{p}^{*}$ ligands and $\sigma-\pi$ interactions between terminal halogen atoms and $\mathrm{Cp}^{*}$ ligands (or $\mathrm{X} \cdot . \cdot \pi$ interactions), ${ }^{[22]}$ in addition to van der Waals interactions.

Two types of $\pi$ stacking were observed: classical face-toface and slipped or offset. ${ }^{[23]}$ Both can involve two spherical moieties (Figure $5 \mathrm{a}$ ) or a spherical moiety and solvent molecules having a $\pi$ system like 1,2-dichlorobenzene or acetonitrile (Table $2 S$ in Supporting Information). Direct contacts between spherical moieties are more frequent for $\mathrm{X}=\mathrm{Cl}$, for which the opportunity for $\pi-\pi$ interactions with solvent molecules is low due to the solvent mixtures used in crystallization. Simple interactions between a spherical moiety and solvent molecules are excluded from the present discussion. We found such interactions in all structures with molecules of solvation having a $\pi$ system, except for 2 and 4 , in which acetonitrile molecules do not participate in these interac-
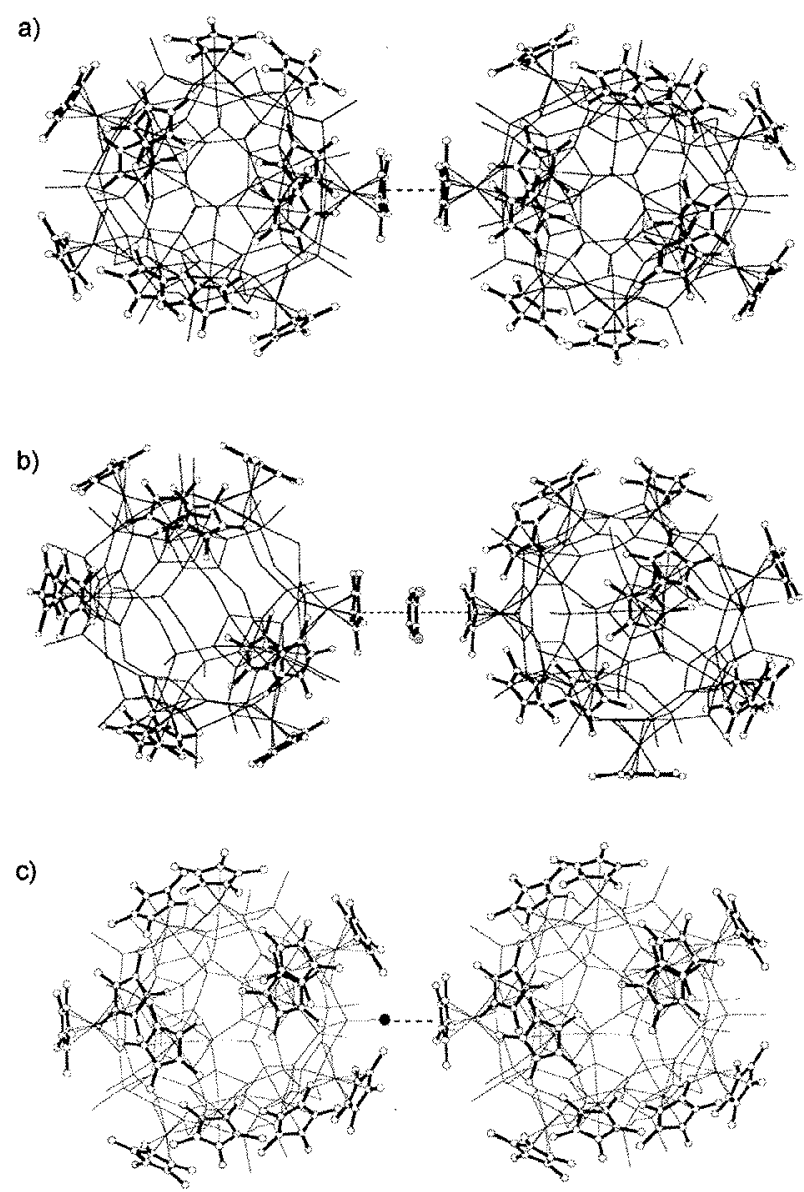

Figure 5. Different types of specific intermolecular contacts between spherical moieties: $\mathrm{Cp}^{*} \ldots \mathrm{Cp}^{*} \pi$ stacking, a) direct in $1 \mathrm{a}$ and b) indirect in $\mathbf{6}$, and $\mathrm{c}$ ) $\mathrm{Br} \cdots \mathrm{Cp} p^{*}$ interaction of $\sigma-\pi$ type in 7 .

tions. Actually, in 2 there are no specific intermolecular interactions at all, owing to the bulky $\mathrm{Cp}^{\mathrm{Et}}$ ligand. However, in three of the nine crystal structures (5-7) triple-decker $\pi-$ $\pi$ interactions involving two spherical moieties that sandwich a solvent molecule are found for 1,2-dichlorobenzene (Figure $5 \mathrm{~b}$ ) and for one example of an acetonitrile solvate (Table $2 S$ in Supporting Information). The distances between $\pi$ systems in 5-7 are mostly 3.3-3.6 $\AA$, while typical values are about $3.5 \AA^{[23]}$

Intriguingly, $\mathrm{X} \cdots \pi$ interactions $(\mathrm{X}=\mathrm{Cl}$ or $\mathrm{Br}$, Figure $5 \mathrm{c})$ are found for all spherical $\mathrm{Cp}^{*}$-containing moieties. The geometry of these intermolecular contacts is always the same: The $\mathrm{Cu}-\mathrm{X}$ bond strictly points to the center of a $\mathrm{Cp}^{*}$ ligand. The distances between the $\mathrm{X}$ atom and the center of the $\mathrm{Cp} *$ ring are $3.21-4.51 \AA$ for $\mathrm{Cl} \cdots \pi$ and $3.33-3.99 \AA$ for $\mathrm{Br} \cdot . \cdot \pi$ contacts, while literature data range from about 3.13 to $3.70 \AA$ for both types of contacts. ${ }^{[22, c]}$ According to Table 2S (Supporting Information) this type of intermolecular interactions between spherical moieties occurs more frequently than $\pi-\pi$ interactions. The number of such contacts per spherical unit varies from four to seven, except for com- 
pound 4 , in which $\pi-\pi$ interactions predominate (six $\pi-\pi$ against two $\sigma-\pi$ contacts). This is not surprising in view of 24-26 CuX $\mathrm{Cerm}_{\text {in }}$ comparison with only twelve $\mathrm{Cp}^{*}$ fragments per spherical moiety. Note that in the crystal structures of 8 and 9 only $X_{\text {term }} \cdots \pi$ interactions are found.

By means of specific contacts of both types, the quasispherical units can associate into infinite architectures, as shown in Figure $6 \mathrm{a}$ and $\mathrm{b}$ for $\pi-\pi$ and $\sigma-\pi$ contacts, respectively. Each spherical unit has specific contacts with the neighbouring ones. The number of specific contacts per

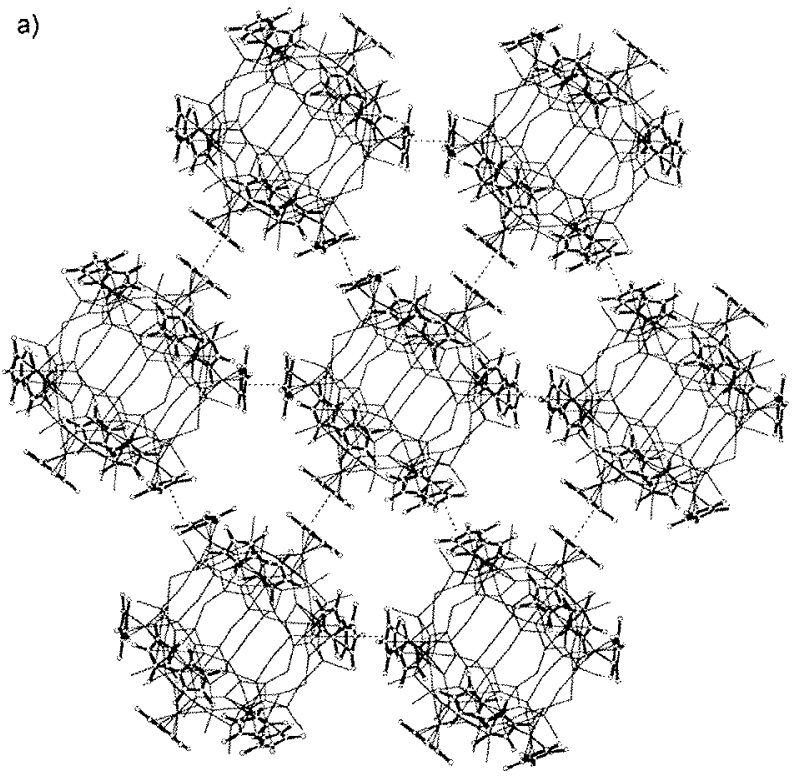

b)

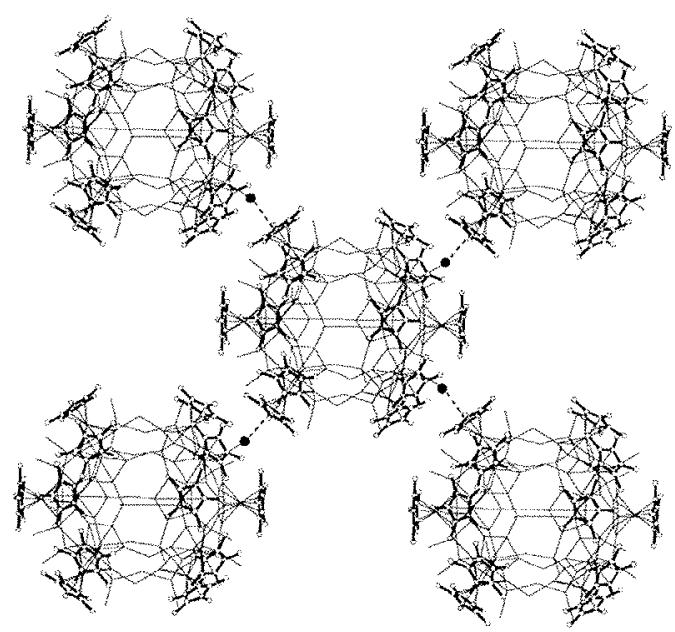

Figure 6. a) Fragment of a layer of $\left[\left\{\mathrm{Cp} * \mathrm{Fe}\left(\eta^{5}-\mathrm{P}_{5}\right)\right]_{12}[\mathrm{CuCl}]_{25}(\mathrm{MeCN})_{10}\right]$ molecules based on face-to-face and slipped $\pi$-stacking contacts $\mathrm{Cp}^{*} \ldots \mathrm{Cp} \mathrm{C}^{*}$ of $3.54-4.42 \hat{A}$ in 4 , and $\mathrm{b}$ ) on specific contacts $\mathrm{Br} \ldots \mathrm{Cp} \mathrm{p}^{*}$ of $\sigma-\pi$ type $(3.36 \AA)$ in 8 . Black balls denote bromine atoms participating in $\alpha-\pi$ interactions; dashed lines show specific contacts. Hydrogen atoms and acetonitrile molecules are omitted; pseudo-spherical core atoms are shown by sticks.

spherical unit is always much smaller than the number of spherical units around a given unit.

Crystal packing of $\left[\left\{\mathrm{Cp}^{*} \mathrm{Fe}\left(\eta^{5}-\mathrm{P}_{5}\right)\right\}_{12}[\mathrm{CuX}\}_{25}(\mathrm{MeCN})_{10}\right]$ molecules and related moieties: Hard equisized spheres are well-known to form face-centered cubic ( $\mathrm{fcc}$ ) or hexagonal close-packed (hcp) arrangements as the closest packings, ${ }^{[24,25]}$ although no strict proof has been given up to now. ${ }^{[26]}$ These fcc and hcp packings, together with body-centered cubic (bcc), were shown to be typical for various textbook monomolecular organic ${ }^{[27,28]}$ and inorganic ${ }^{[29]} \mathrm{com}$ pounds containing molecules of the same chemical sort.

However, if other smaller hard spheres are added, the packing motif of the bigger ones becomes unpredictable. Small spheres could either fill the voids in the packing of bigger ones, or isolate bigger ones from direct interactions and thus disturb their packing. Analogously, in the packing of huge spherical moieties in 1-9 the intermolecular cavities are large enough to accommodate several molecules of solvation such as THF, acetonitrile, 1,2-dichlorobenzene, toluene, or dichloromethane, which are partly disordered even at low temperatures. The sandwiching of spherical moieties with stacked molecules of solvation is also possible. However, we have found that the quasi-spherical moieties in 1-9 preferably pack according to motifs typical for the packing of equisized balls. ${ }^{[24]}$ Indeed, hcp (ABAB...) is found in 1, 4, 6, and 7 (Figure 7), while the fcc (ABCABC...) motif appeared in 8 and 9 (Figure 8). The packing motifs of 2,3 and

a)

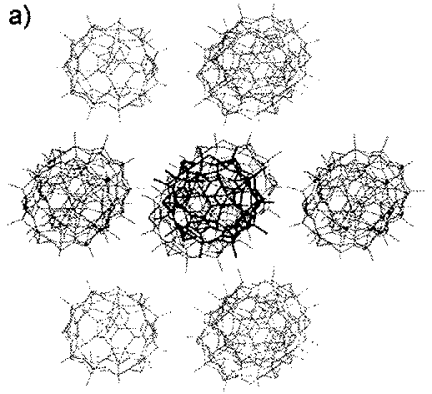

Figure 7. Two-layered packing (hcp, ABAB ...) of $\left[\mathrm{Cp} * \mathrm{Fe}\left(\eta^{5}-\mathrm{P}_{5}\right)\right] @$ $\left[\left[\mathrm{Cp} * \mathrm{Fe}\left(\eta^{5}-\mathrm{P}_{5}\right)\right]_{12}[\mathrm{CuBr}]_{25}(\mathrm{MeCN})_{10}\right]$ molecules in 7 (a) in comparison with ideal hcp packing (b). Different trigonal layers are marked in different greyscale. The hydrogen, carbon and nitrogen atoms are omitted.

5 belong to less well known topological types. However, the nearest environments of molecules in 2 and 3 resemble the bcc lattice motif (Figure 9). The distances between the centres of spherical units in the packing of mainly about 20$26 \AA$ reveal that all the packings are geometrically distorted (Table 3 ). Some moieties are in direct contact, sometimes supported by specific intermolecular interactions, while others are affected by sandwiching of ordered solvent molecules or eclipsing by disordered solvent molecules. Summarising, $\pi-\pi$ stacking and $\sigma-\pi$ interactions may directly or indirectly influence the packing of spherical moieties. Howev- 


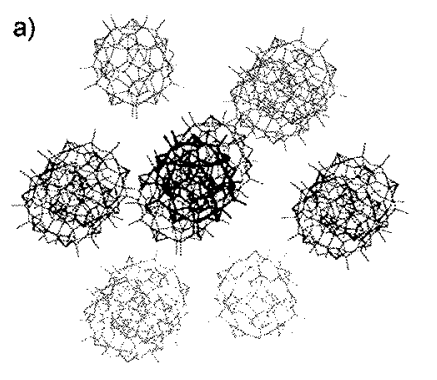

b)

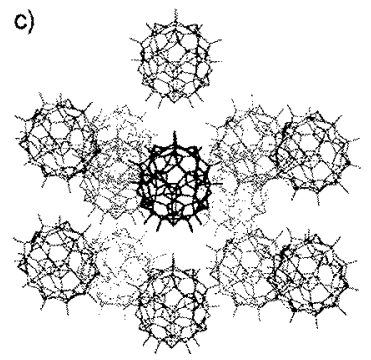

Figure 8. Three-layered packing (fcc, $\mathrm{ABCABC} \ldots$ ) of $\left[\mathrm{Cp} * \mathrm{Fe}\left(\eta^{5}-\mathrm{P}_{5}\right)\right] @$ $\left[\left[\mathrm{Cp} * \mathrm{Fe}\left(\eta^{5}-\mathrm{P}_{5}\right)\right\}_{12}(\mathrm{CuBr}]_{25}(\mathrm{MeCN})_{10}\right]$ molecules shown in two orientations (a and c) in 8 in comparison with its ideal view (b). Different trigonal layers are marked in different greyscale. The hydrogen, carbon and nitrogen atoms are not shown.

er, the small number of these contacts $\left(N_{1}^{\prime}\right.$, Table $2 S$ in Supporting Information) generally does not allow organized $3 \mathrm{D}$ crystal packing through the specific contacts alone. In other words, $N_{1}^{\prime}$ is systematically smaller than $N_{1}$ (Table $2 S$ in Supporting Information). Therefore, distorted hcp or fcc motifs may not be the result of direct interactions between large molecules, so that the reason for their realization is not obvious.

Moreover, the nets of centroids of the spherical units were constructed with considerable weak van der Waals interactions between the outer atoms of the units. The coordination numbers of the net nodes are much lower, as a rule, than the connectivity of the closest sphere packings (Table 3), so these types of interactions also cannot sustain hcp, fcc, or bcc motifs. The packing of large quasi-spherical moieties can be the result of long-range interactions that force the units to occupy the most symmetrical and most uniformly arranged positions in the crystal space (cf. refs. $[28,30])$.

Redox properties: Due to their formation in mixtures of $\mathrm{CH}_{3} \mathrm{CN}$ and other solvents, the 90 -vertex spherical moieties are soluble. For crystallization the solutions are usually layered with nonpolar solvents like pentane. After isolation in the solid state the crystals tend to lose solvent molecules incorporated in the crystal lattice, which, on the one hand, is disadvantageous for the X-ray diffraction properties (insufficient diffraction at high angles). On the other hand, the ability for redissolution decreases with increasing isolation time. Thus, freshly isolated crystals are sufficiently soluble to be
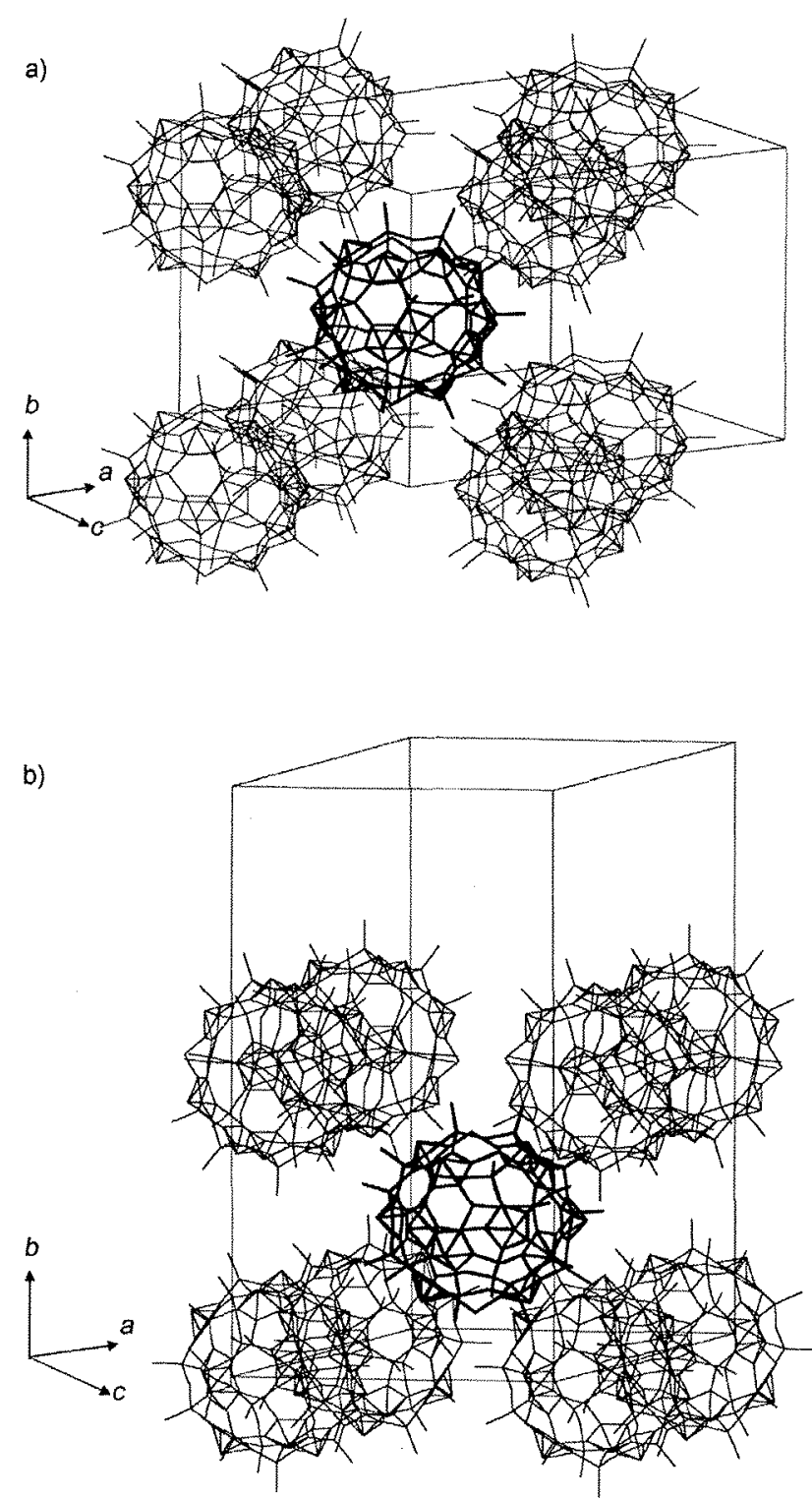

Figure 9. Fragment of the distorted bcc crystal packing of $\left[\left\{\mathrm{Cp} * \mathrm{Fe}\left(\eta^{5}\right.\right.\right.$ $\left.\mathrm{P}_{5}\right)\left.\right|_{12}\left[\left.\mathrm{CuX}\right|_{25}(\mathrm{MeCN})_{10}\right]$ molecules in a) $2(\mathrm{X}=\mathrm{Br})$ and $\left.\mathrm{b}\right) 3(\mathrm{X}=\mathrm{Cl})$. The hydrogen carbon and nitrogen atoms of spherical moiety and all solvent molecules are omitted for clarity.

investigated by solution-state ${ }^{31} \mathrm{P}$ NMR spectroscopy and show broad signals at about $68 \mathrm{ppm}$, similar to those measured in the solid state by ${ }^{31} \mathrm{P}$ MAS NMR spectroscopy (see below). Moreover, small signals for encapsulated $\left[\mathrm{Cp} * \mathrm{Fe}\left(\eta^{5}-\right.\right.$ $\left.\mathrm{P}_{5}\right)$ ], shifted downfield in comparison with the free compound, are found in the spectra.

The solubility of freshly prepared 1 also suffices for electrochemical investigations in a $\mathrm{CH}_{2} \mathrm{Cl}_{2} / \mathrm{CH}_{3} \mathrm{CN}(3 / 1) / \mathrm{NBu}_{4}{ }^{+}$ $\mathrm{PF}_{6}{ }^{-}$electrolyte. Three individual redox waves are observed within the potential range of this solvent mixture (Figure 10). These are an irreversible oxidation at a peak potential of $0.615 \mathrm{~V}$ (peak A in Figure 10), and two reduc- 
Table 3. Crystal packing motifs of $\left[\left[\mathrm{Cp}^{*} \mathrm{Fe}\left(\eta^{5}-\mathrm{P}_{5}\right)\right]_{12}\left\{\left.\mathrm{CuX}\right|_{25}(\mathrm{MeCN})_{10}\right](\mathrm{X}=\mathrm{Cl}, \mathrm{Br})\right.$ molecules and derivative ionic pairs in the crystal structures of 1-9.[a]

\begin{tabular}{|c|c|c|c|c|c|c|}
\hline Compd & $Z^{\prime}$ & $\begin{array}{l}\text { Coordination } \\
\text { sequences } \\
\left\{N_{1-1}\right\} \text { for } \\
\text { packing/net }\end{array}$ & $\begin{array}{l}\text { Symbol of } \\
\text { packing/net.motif }\end{array}$ & $\begin{array}{l}\text { Uniformity } \\
\text { criterion } \\
G_{3}\end{array}$ & $\begin{array}{l}\text { Centre...centre } \\
\text { distances }[\AA]\end{array}$ & Reference \\
\hline 1 & 2 & $\begin{array}{l}12,44,96 \\
\mathbf{1 1}, \mathbf{3 8}, \mathbf{8 3} \\
\mathbf{1 0}, \mathbf{3 6}, \mathbf{8 3}\end{array}$ & $\begin{array}{l}h c p \\
-\end{array}$ & 0.07900 & $21.1-23.5$ & [7a] \\
\hline 2 & 1 & $\begin{array}{l}13,47,103 \\
\mathbf{9}, \mathbf{3 1}, \mathbf{6 7}\end{array}$ & $\begin{array}{l}{[28\}} \\
\mathbf{n c j}\end{array}$ & 0.07871 & $22.1-26.4$ & [7] \\
\hline 3 & 2 & $\begin{array}{l}14,50,110 \\
13,49,110 \\
\mathbf{1 0}, \mathbf{3 4}, \mathbf{7 4} \\
\mathbf{9 , 3 3}, \mathbf{7 4}\end{array}$ & - & 0.07887 & $21.0-25.7$ & this work \\
\hline 4 & 1 & $\begin{array}{l}12,44,96 \\
\mathbf{8}, \mathbf{2 6}, \mathbf{5 6}\end{array}$ & $\begin{array}{l}h c p \\
\text { hex }\end{array}$ & 0.07906 & $22.0-25.7$ & this work \\
\hline 5 & 1 & $\begin{array}{l}12,44,94 \\
11,42,96 \\
\mathbf{9}, \mathbf{3 0}, \mathbf{6 7} \\
\mathbf{8}, \mathbf{3 1}, \mathbf{6 5}\end{array}$ & - & 0.08019 & $19.7-26.5$ & this work \\
\hline 6 & 1 & $\begin{array}{l}12,44,96 \\
\mathbf{8}, \mathbf{2 6}, \mathbf{5 6}\end{array}$ & $\begin{array}{l}h c p \\
\text { hex }\end{array}$ & 0.07957 & $21.8-26.3$ & this work \\
\hline 7 & 2 & $\begin{array}{l}12,44,96 \\
4,8,12\end{array}$ & $\begin{array}{l}h c p \\
\text { sql }\end{array}$ & 0.07992 & $21.9-26.2$ & this work \\
\hline 8 & 1 & $\begin{array}{l}12,42,92 \\
\mathbf{6}, \mathbf{1 8}, \mathbf{3 8}\end{array}$ & $\begin{array}{l}f c c \\
\text { pcu }\end{array}$ & 0.08036 & $22.1-30.3$ & this work \\
\hline 9 & 1 & $\begin{array}{l}12,42,92 \\
\mathbf{6}, \mathbf{1 8}, \mathbf{3 8}\end{array}$ & $\begin{array}{l}f c c \\
\text { pcu }\end{array}$ & 0.07985 & $22.2-28.6$ & this work \\
\hline
\end{tabular}

[a] $Z^{\prime}$ is the number of crystallographically unique spherical moieties; in molecular packing the coordination sequence $\left\{N_{k}\right\}, k=1,2,3 \ldots$, is the set of integers corresponding to the number of molecules in first, second and more distant coordination spheres up to desired $k{ }^{[42,55]} \mathrm{hcp}=$ hexagonal close, bcc $=$ body-centered cubic, $\mathrm{fcc}=$ face-centered cubic; three-letter symbols of nets are given according to the RCSR notation ${ }^{[56]}$ the data for packing graphs and nets of centroids are italicized and boldfaced, respectively; $G_{3}$ is the uniformity criterion for lattices; the lower the $G_{3}$ value the higher uniformity of the lattice. The minimum $G_{3}$ value known for 3D periodic nets is for ideal bcc packing (0.07854). The ideal fcc and hcp packings have $G_{3}=0.07875$. pared to that of the first reduction peak, a ratio of 2.87 to 3.06 is obtained. This is close to the theoretical value of 2.83 for two waves that are associated with $2 n$ and $n$ electrons, respectively. The first reduction occurs as a rather sharp peak with a half-width of about $30 \mathrm{mV}$. This is substantially less than the theoretical $E_{\mathrm{p}}-E_{\mathrm{p} / 2}$ value of $57 \mathrm{mV}$ for a one-electron wave under ambient conditions and thus points to a multielectron event, adsorption, or both. If, after scanning past this wave, the initial sweep direction is reversed, an anodic peak appears some $320 \mathrm{mV}$ to the positive side of the reduction (peak D in Figure 10). This feature displays strongly adsorptive behaviour, as is evident from its distinctive shape and peak current, which often surpasses that of the initial cathodic peak (Figure 11). Increasing the sweep rate or decreasing the temperature lead to even stronger distortions of peaks A and $\mathbf{D}$ from ideal shape. The

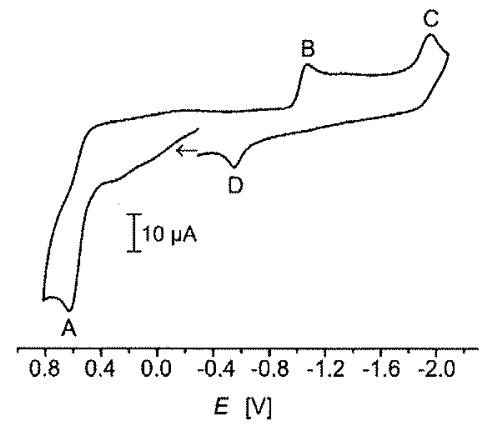

Figure 10. $\mathrm{CV}$ on 1 in $\mathrm{CH}_{2} \mathrm{Cl}_{2} / \mathrm{CH}_{3} \mathrm{CN}(3 / 1) / \mathrm{Bu}_{4} \mathrm{NPF}_{6}^{-}$solution at $\mathrm{RT}$ and $v=0.2 \mathrm{Vs}^{-1}$.

tions at peak potentials of approximately -1.10 and $-2.0 \mathrm{~V}$ $\left(v=0.2 \mathrm{Vs}^{-1}{ }^{-1}\right.$ peaks B and $\mathrm{C}$ in Figure 10). Both reductions seem to be associated with approximately the same peak height, but individual peak currents were difficult to reproduce even under otherwise identical conditions due to severe electrode passivation upon scanning these waves. The anodic peak is always preceded by a broad and ill-defined shoulder which may be point to the presence of another, unresolved feature. If the anodic peak current is measured from the plateau of this feature as the baseline and com-

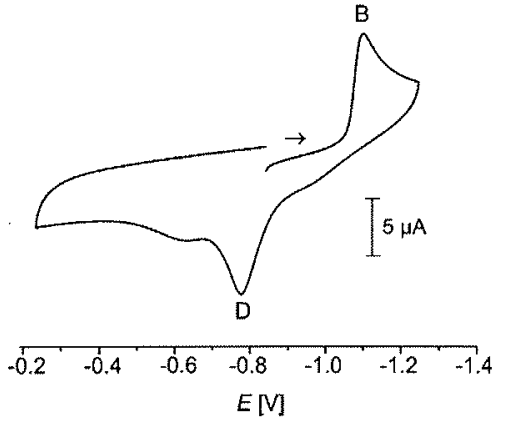

Figure 11. $\mathrm{CV}$ on the first reduction of $\mathbf{1}$ (peak $\mathrm{B}$ ) and the associated return peak (peak $\mathrm{D}$ ) in $\mathrm{CH}_{2} \mathrm{Cl}_{2} / \mathrm{CH}_{3} \mathrm{CN}(3 / 1) / \mathrm{Bu}_{4} \mathrm{NPF}_{6}$ solution at $\mathrm{RT}$ and $\nu=0.1 \mathrm{Vs}^{-1}$

second reduction at a substantially more negative potential is altogether irreversible. Due to the adsorptive behaviour, peak potentials of peaks B-D vary by up to $100 \mathrm{mV}$ between different scans, even under otherwise identical conditions. Qualitatively similar results with the same general problems of adsorption of particularly the reduced species onto the working electrode were obtained for the related CuBr-derived cluster 8. Peak potentials are $+0.58 \mathrm{~V}$ (peak A), $-1.05 \mathrm{~V}$ (peak B), $-1.95 \mathrm{~V}$ (peak C) and $-0.54 \mathrm{~V}$ 
(peak D; c.f. Supporting Information). In some of the voltammograms a broad feature preceding the main anodic peak $\mathrm{A}$ by about $250 \mathrm{mV}$ was resolved.

To establish the number of electrons associated with the first reduction and to probe the chemical stability of the reduced form, quantitative coulometry experiments were performed. Bulk electrolysis of a solution containing $14.5 \mathrm{mg}$ of $1(1.843 \mu \mathrm{mol}$ based on a molecular mass of $7865.35 \mathrm{a} . \mathrm{u}$.) at a potential of $-1.30 \mathrm{~V}$ consumed $2.07 \mathrm{C}$ of charge, while the colour of the solution intensified to greyish green. Our results thus point to transfer of 12 electrons during the first reduction step (calculated value: 11.6 electrons). Voltammograms after reduction revealed essentially the same features as for the starting compound; only the current sense of peaks $\mathrm{B}$ and $\mathrm{D}$ had reversed. Back electrolysis at $-0.75 \mathrm{~V}$ released $1.98 \mathrm{C}$ of charge and reproduced the starting material in almost quantitative yield with no signs of other electroactive species apparent in the reoxidized solution. These results attest to the overall chemical stability of reduced 1 . The likely reason for the large wave splitting of associated peaks $B$ and $D$ is a major structural rearrangement within the cluster core of $\mathbf{1}$ upon multi-electron reduction. The number $n=12$ of transferred electrons was also confirmed by comparing the limiting currents from steady state voltammetry and the slope of $i$ versus $t^{-1 / 2}$ plots in chronoamperometry of 1 to those of the ferrocene standard according to the method of Baranski et al. ${ }^{[31]}$ which gave a value of $n=$ 12.3.

Additional attempts to establish the coulomb counts for the second reduction and the oxidations were thwarted by electrode passivation during electrolysis, linear sweep voltammetry and chronoamperometry experiments. In view of these difficulties our only guess to the number of electrons transferred upon oxidation relies on the above-mentioned ratio of the anodic and cathodic peak currents of peaks $A$ and $\mathrm{B}$. The thus-derived value of $n=24$ may, however, be erroneously large due to the presence of the broad unresolved feature to the negative side of this wave and sloping of the background current.

Neither the reduced nor the partially oxidized solution gave any ESR signal at room temperature or at $77 \mathrm{~K}$, so no hint as to the identity of the redox sites within 1 could be gleaned from those experiments. We note that the first oxidation and the second reduction potential of 1 resemble those of the parent pentaphosphaferrocene $\left[\mathrm{Cp} * \mathrm{Fe}\left(\eta^{5}-\mathrm{P}_{5}\right)\right]$ $\left(E_{1 / 2}{ }^{0 /+}=+0.57 \mathrm{~V}, E_{\mathrm{p}}=0.60 \mathrm{~V}\right.$ in the irreversible limit, and $\left.E_{\mathrm{p}}^{\mathrm{red}}=-2.00 \mathrm{~V}\right){ }^{[32]}$

Theoretical calculations: Density functional calculations were carried out to shed light on the encapsulation of $\left[\mathrm{Cp} * \mathrm{Fe}\left(\eta^{5}-\mathbf{P}_{5}\right)\right]$ and host-guest interactions in $\mathbf{1 a}$, the NMR spectroscopic data and the redox behaviour. To speed up calculations the $\mathrm{Cp}^{*}$ moieties in $\mathbf{1 a}$ were replaced by $\mathrm{Cp}$ to give model complex Ia. The resulting structure has $D_{5 h}$ symmetry. Encapsulating $\left[\mathrm{Cp} * \mathrm{Fe}\left(\eta^{5}-\mathbf{P}_{5}\right)\right]$ inside Ia leads to lowering of the symmetry that depends on the mutual orientation of host and guest. For calculation purposes we chose both the axial and equatorial orientations of $\left[\mathrm{Cp} * \mathrm{Fe}\left(\eta^{5}-\mathrm{P}_{5}\right)\right]$ mentioned earlier. In the axial orientation the $C_{5}$ axes of both molecules coincide and the resulting compound Ib shows $C_{5 v}$ molecular symmetry (Figure $4 \mathrm{~b}$ ). In the equatorial structure $\left[\mathrm{Cp} * \mathrm{Fe}\left(\eta^{5}-\mathrm{P}_{5}\right)\right]$ is rotated perpendicular to its $C_{5}$ axis by about $45^{\circ}$ to give complex Ic with $C_{s}$ symmetry (Figure $4 \mathrm{a})$. The calculated reaction energies (SV(P) basis set) for encapsulating $\left[\mathrm{Cp} * \mathrm{Fe}\left(\eta^{5}-\mathrm{P}_{5}\right)\right]$ inside host $\mathbf{I a}$ are -11 and $-8 \mathrm{~kJ} \mathrm{~mol}^{-1}$ for Ib and $\mathbf{I c}$, respectively. Increasing the basis set for $\mathbf{I b}$ to TZVP yields a slightly endothermic reaction of $40 \mathrm{kJmol}^{-1}$. These results show that encapsulation of $\left[\mathrm{Cp} * \mathrm{Fe}\left(\eta^{5}-\mathrm{P}_{5}\right)\right]$ in the final stage is, energetically, almost a neutral process. This is in agreement with the partial occupation observed in the crystal structure of some products. The small energetic difference between two orientations of the guest molecule in Ib and Ic points to a relatively large rotational freedom of the guest molecule inside the fullerene-like host.

Table 4 compares the most important calculated and experimental structural parameters for complexes Ia-Ic. The results of our calculations are in good agreement with observed structural data for 1a, although most of the calculated bond lengths are slightly overestimated. Comparison of results obtained by using SV(P) and TZVP basis sets for complexes Ia and $\mathbf{I b}$ shows almost negligible influence of the basis set on calculated bond lengths. There are also no pronounced differences between the structures of the host molecule alone (Ia) and when $\left[\mathrm{Cp} * \mathrm{Fe}\left(\eta^{5}-\mathrm{P}_{5}\right)\right]$ is encapsulated inside to form Ib and Ic, demonstrating that, $\mathbf{I}$ a can relatively easily encapsulate molecules of the size of $\left[\mathrm{Cp} * \mathrm{Fe}\left(\eta^{5}-\right.\right.$ $\left.P_{5}\right)$ ]. Figure 12 schematically shows changes of the structure

Table 4. Comparison of selected calculated (SV(P) and TZVP basis sets) bond lengths [pm] for model compounds Ia, Ib, and Ic and experimental data for 1 a.

\begin{tabular}{llllll}
\hline Parameter & & Ia & & Ib & Exptl (1a) \\
& SV(P) & TZVP & SV(P) & TZVP & $\begin{array}{l}\text { Ic } \\
\text { SV(P) }\end{array}$ \\
\hline $\mathrm{P}-\mathrm{P}$ & $213.7-215.3$ & $214.1-215.8$ & $213.5-216.6$ & $214.1-216.2$ & $213.4-215.9$ \\
$\mathrm{Cu}(2)^{[a]-P}$ & 232.0 & 234.1 & $232.5-232.7$ & $234.7-234.9$ & $232.0-232.8$ \\
$\mathrm{Cu}-\mathrm{P}$ & $232.7-233.3$ & $232.7-234.4$ & $232.9-234.0$ & $232.9-235.4$ & $231.3-239.2$ \\
$\mathrm{Cu}-\mathrm{Cl}(1)^{[b]}$ & $220.1-224.0$ & $221.4-225.2$ & $220.3-224.1$ & $221.7-225.4$ & $220.1-224.9$ \\
$\mathrm{Cu}-\mathrm{Cl}(2)^{[b]}$ & 237.0 & 236.8 & $237.1-239.1$ & $236.4-238.7$ & 21.3 \\
$\mathrm{Cu}-\mathrm{N}$ & 195.8 & 196.8 & 195.9 & 196.9 & $236.9-238.4$ \\
$\mathrm{Fe}-\mathrm{P}$ & $236.2-241.2$ & $237.6-241.5$ & $236.2-242.1$ & $237.6-242.1$ & $195.5-196.5$ \\
$\mathrm{Fe}-\mathrm{C}$ & $207.7-209.2$ & $209.0-210.4$ & $207.7-209.2$ & $209.0-210.4$ & $235.7-245.0$ \\
\hline
\end{tabular}

[a] $\mathrm{Cu}$ atom coordinated to two $\mathrm{P}$ and two $\mathrm{N}$ atoms. [b] $\mathrm{Cl}$ atom coordinated to one $\mathrm{Cu}$ atom. [c] $\mathrm{Cl}$ atom coordinated to two $\mathrm{Cu}$ atoms. 

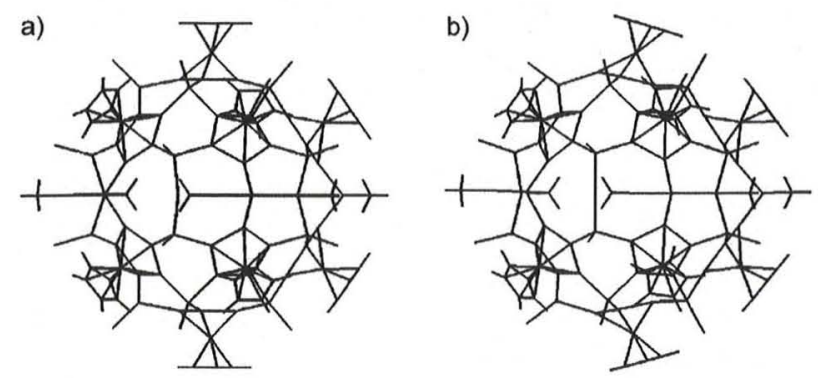

Figure 12. Changes of the structure of the fullerene-like host molecule for the two orientations of the guest in Ib and Ic (guest molecule is omitted for clarity).

of the host molecule between two different orientations of the guest in Ib and Ic. Although the shape of the host undergoes relatively large changes when the guest molecule is rotated inside, the bond lengths remain almost unchanged.

Figure 13 compares the calculated ${ }^{31} \mathrm{P}$ NMR spectrum of Ib and experimental spectrum of $\mathbf{1}$ a. The calculated spec-

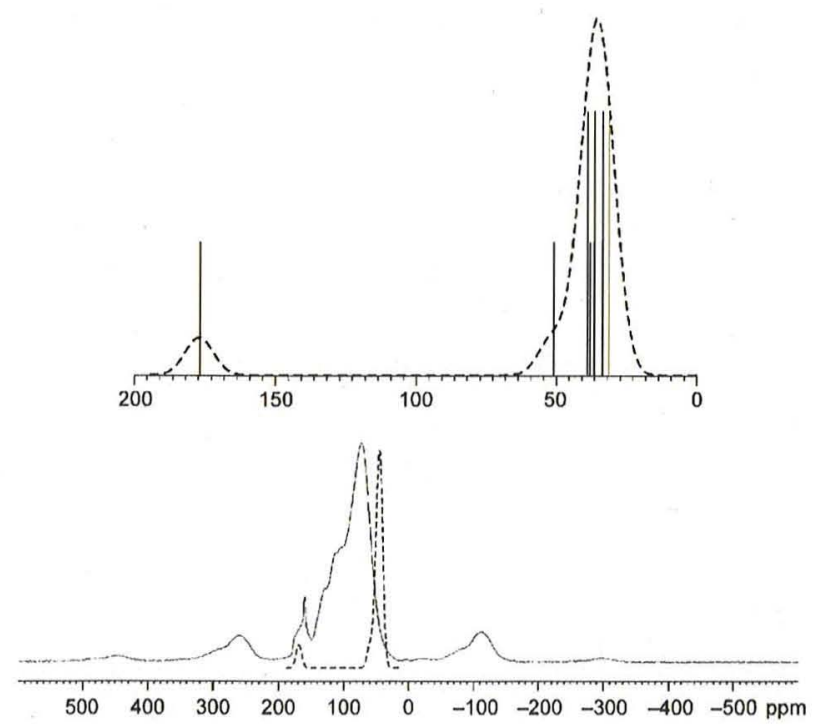

Figure 13. Calculated (Ib) and observed (Ia) ${ }^{31} \mathrm{P}$ NMR spectra. Top: individual calculated signals and the results of Gaussian convolution. Bottom: comparison of experimental and calculated spectra.

trum shows two maxima, one at 35 and the second at $177 \mathrm{ppm}$. The peak at $35 \mathrm{ppm}$ consists of eight signals between 32 and $51 \mathrm{ppm}$ due to symmetry-inequivalent $P$ atoms of the fullerene-like host. Thus, the experimentally observed signal with maximum at about $60 \mathrm{ppm}$ is assigned to these $\mathrm{P}$ atoms, although the calculated signal is shifted by about $25 \mathrm{ppm}$. The peak at $177 \mathrm{ppm}$ consists of a single signal assigned to the $\mathrm{P}$ atom of encapsulated $\left[\mathrm{Cp} * \mathrm{Fe}\left(\eta^{5}-\mathrm{P}_{5}\right)\right]$. It clearly corresponds to the experimentally observed signal at $160 \mathrm{ppm}$. Thus, the results of our calculations allows for assignment of the experimentally observed ${ }^{31} \mathrm{P}$ signals.
To investigate the redox behaviour of $\mathbf{1}$ we computed isosurfaces of differences in electron densities between anion (total charge $-12 \mathrm{e}$ ) and neutral species as well as cation (total charge $+12 e$ ) and neutral species of Ib (Figure 14). Inspection of the calculated isosurfaces clearly shows that charge accumulation and depletion in anion and cation, respectively, occur only in the $\mathrm{Cp}$ rings and at the $\mathrm{Fe}$ and $\mathrm{Cl}$ atoms. In both anion and cation virtually no charge changes on the $\mathrm{Cu}$ atoms, in agreement with experimental observations.
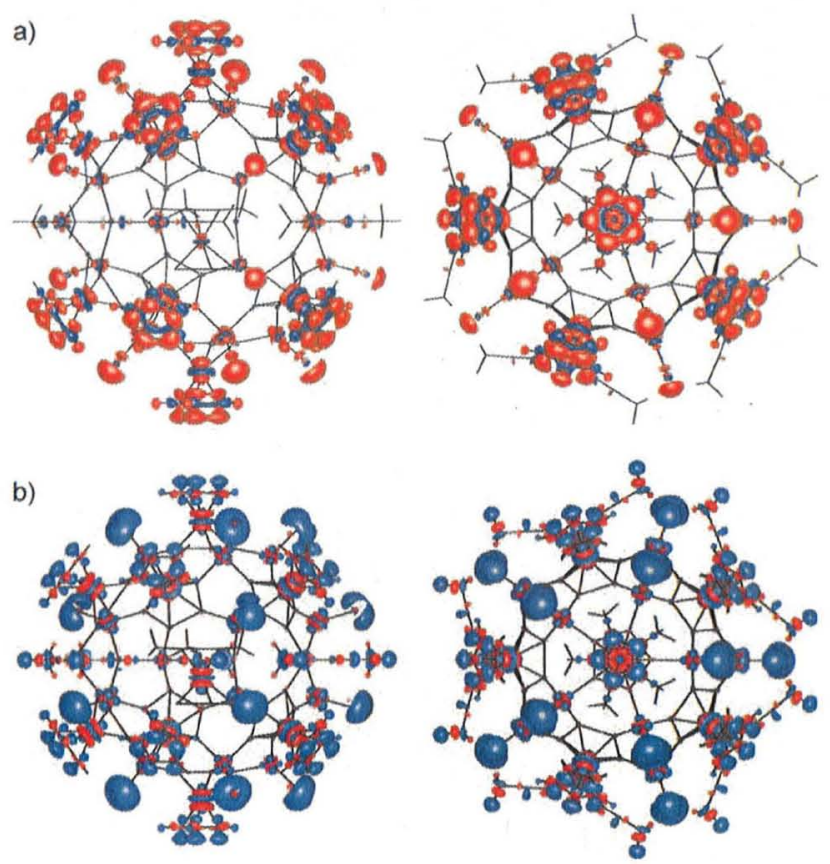

Figure 14. Isosurfaces of the difference between electron densities of a) anion and neutral structure and b) cation and neutral structure of $\mathbf{I b}$. Red indicates charge accommodation and blue charge depletion.

\section{Conclusion}

By using the right stoichiometry and dilution conditions, exclusive formation of spherical molecules from the $[\mathrm{Cp} * \mathrm{Fe}-$ $\left.\left(\eta^{5}-\mathrm{P}_{5}\right)\right] / \mathrm{CuX}(\mathrm{X}=\mathrm{Cl}, \mathrm{Br})$ system is favored over polymer formation. The products form 90 -vertex frameworks with fullerene-like topologies. Since each spherical molecule has one encapsulated $\left[\mathrm{Cp} * \mathrm{Fe}\left(\eta^{5}-\mathrm{P}_{5}\right)\right]$ molecule, its presence seems to be decisive for the formation of spherical structures. This is supported by the observed preferential orientation of the cyclo- $\mathrm{P}_{5}$ ring of the guest towards a cyclo- $\mathrm{P}_{5}$ ring of the host sphere in the voids of the nanoballs, which have diameters of about $1.24-1.28 \mathrm{~nm}(\mathrm{X}=\mathrm{Cl})$ and $1.32-1.20 \mathrm{~nm}$ $(\mathrm{X}=\mathrm{Br})$. Although DFT calculations reveal only small energy differences between the preferred orientations of the guest in the spherical molecule and not much gain in total energy of the final host-guest molecule in comparison to the guest-free system, $\pi-\pi$ interaction should play a decisive role during the formation of the spheres as opposed to ther- 
modynamically favoured polymer formation. In the crystal lattice, the spherical molecules, up to $2.24 \times 2.18 \mathrm{~nm}(\mathrm{X}=\mathrm{Cl})$ and $2.26 \times 2.22 \mathrm{~nm}(\mathrm{X}=\mathrm{Br})$. in size, form hcp, fcc or bcc packing motives, which show partial $\pi-\pi$ (between the $P_{5}$ rings) and $\sigma-\pi$ (between the halogen atom and the $P_{5}$ rings) interactions. In the voids of the packing of spherical nanomolecules a large number of solvent molecules are embedded. During isolation of the products their loss decreases the otherwise good solubility of these nanostructured molecules. Investigation of the redox behaviour reveals one almost irreversible multi-electron oxidation and two reduction processes. The first reduction corresponds to about 12 electrons, and spectroelectrochemical investigations show that no paramagnetic species like $\mathrm{Cu}^{2+}$ are involved in these processes. In accordance, the differences in electron densities between the neutral molecules and the 12-electron-reduced or -oxidized species, calculated by DFT methods, reveal that the electrons are added or withdrawn at the $\mathrm{Cp}^{*}$ and halogen ligands, and at the $\mathrm{Fe}$ atoms. Consequently, surface-directed redox behaviour occurs.

\section{Experimental Section}

General remarks: All manipulations were carried out under an atmosphere of dinitrogen or argon by using standard Schlenk techniques. All solvents were dried by standard procedures and distilled freshly prior to use. $\left[\mathrm{Cp} * \mathrm{Fe}\left(\eta^{5}-\mathrm{P}_{5}\right)\right],{ }^{[33]} \mathbf{1}^{[\mathrm{fa}]}$ and $2^{[7 \mathrm{bb}]}$ were prepared according to the literature. Solution NMR spectra were recorded at $25^{\circ} \mathrm{C}$ on a Bruker Avance 400 ( ${ }^{1} \mathrm{H}: 400.132 \mathrm{MHz}$, standard tetramethylsilane, ${ }^{31} \mathrm{P}: 161.976 \mathrm{MHz}$; standard $85 \% \mathrm{H}_{3} \mathrm{PO}_{4}{ }^{13} \mathrm{C}: 100.627 \mathrm{MHz}$, standard tetramethylsilane). ${ }^{31} \mathrm{P}$ MAS NMR spectra were recorded at $162.01 \mathrm{MHz}$ on a Bruker DSX 400 solid-state NMR spectrometer equipped with a $2.5 \mathrm{~mm}$ high-speed spinning probe operated at $30 \mathrm{kHz}$ spinning rate. Spectra were recorded by a rotor-synchronized Hahn spin echo sequence, generated with $90^{\circ}$ pulse lengths of about $4 \mu \mathrm{s}$ and a relaxation delay of $180 \mathrm{~s}$. This delay was shown to be sufficient to produce quantitatively representative spectra. Chemical shifts are reported relative to $85 \%$ phosphoric acid. Additional low-field data were recorded at $121.5 \mathrm{MHz}$ on a Bruker Avance $300 \mathrm{spec}-$ trometer.

In all the performed reactions, we observe the formation of small amounts of polymeric compounds. By working under very dilute conditions and using the right stoichiometries, the amount of polymeric compounds is reduced to only a few crystals per reaction.

Synthesis of $\left[\mathbf{C p} * \mathrm{Fe}\left(\eta^{5}-\mathbf{P}_{5}\right)\right]_{0.5} @\left[\left\{\mathrm{Cp} * \mathrm{Fe}\left(\eta^{5}-\mathrm{P}_{5}\right)\right]_{12}\{\mathrm{CuCl}\}_{25^{*}}\right.$ $(\mathrm{MeCN})_{10} \cdot 6 \mathrm{CH}_{2} \mathrm{Cl}_{2} \cdot 1.5 \mathrm{MeCN}(3)$ : A solution of $\mathrm{CuCl}$ (15 $\mathrm{mg}$, $0.15 \mathrm{mmol})$ in a mixture of $\mathrm{CH}_{3} \mathrm{CN}(3 \mathrm{~mL})$ and $\mathrm{CH}_{2} \mathrm{Cl}_{2}(2 \mathrm{~mL})$ was added to a solution of $1(52 \mathrm{mg}, 0.15 \mathrm{mmol})$ in $\mathrm{CH}_{2} \mathrm{Cl}_{2}(5 \mathrm{~mL})$ at room temperature. This mixture was kept for $2 \mathrm{~d}$ and few yellow crystals of polymers formed. Then the clear solution was transferred into another Schlenk tube and pentane $(10 \mathrm{~mL})$ layered onto the mother solution. This mixture was kept for one week and some brown plate-like crystals of 3 formed. The upper solution was removed by cannula, and the crystals were dried under high vacuum. $(8 \mathrm{mg}, 0.001 \mathrm{mmol}, 8.9 \%)$.

Synthesis of $\quad\left[\mathrm{Cp}^{*} \mathrm{Fe}\left(\eta^{5}-\mathrm{P}_{5}\right)\right]_{0.6} @\left[\left\{\mathrm{Cp}^{*} * \mathrm{Fe}\left(\eta^{5}-\mathrm{P}_{5}\right)\right\}_{12}[\mathrm{CuCl}\}_{25}\right.$ (MeCN) ${ }_{10} \cdot 9.5$ THF.2 MeCN (4): A solution of $\mathrm{CuCl}$ (15 mg, $0.15 \mathrm{mmol}$ ) in a mixture of THF $(5 \mathrm{~mL})$ and $\mathrm{CH}_{3} \mathrm{CN}(5 \mathrm{~mL})$ was carefully layered onto a solution of $\left[\mathrm{Cp} * \mathrm{Fe}\left(\eta^{5}-\mathrm{P}_{5}\right)\right](26 \mathrm{mg}, 0.075 \mathrm{mmol})$ in THF $(10 \mathrm{~mL})$ at room temperature. After slow diffusion, brown single crystals of 4 formed. The crystals were isolated by filtration, washed with $n$-pentane, and dried under vacuum (19 $\mathrm{mg}, 0.0024 \mathrm{mmol}, 20.8 \%$ ).

Synthesis of $\left[\mathrm{Cp}^{*} \mathrm{Fe}\left(\eta^{5}-\mathrm{P}_{5}\right)\right] @\left[\left\{\mathrm{Cp}^{*} \mathrm{Fe}\left(\eta^{5}-\mathrm{P}_{5}\right)\right\}_{12} \mathrm{Cu}_{25} \mathrm{Cl}_{24}(\mathrm{MeCN})_{9}\right]^{+}$ $\left[\left\{\mathrm{Cp} * \mathrm{Fe}\left(\eta^{5}-\mathrm{P}_{5}\right)\right\}_{12} \mathrm{Cu}_{25} \mathrm{Cl}_{26}(\mathrm{MeCN})_{9}\right] \cdot 12 \mathrm{C}_{7} \mathrm{H}_{8} \cdot 1.5 \mathrm{MeCN}(5)$ : A solution of
$\mathrm{CuCl}(32 \mathrm{mg}, 0.32 \mathrm{mmol})$ in $\mathrm{CH}_{3} \mathrm{CN}(8 \mathrm{~mL})$ was layered onto a solution of $\left[\mathrm{Cp} * \mathrm{Fe}\left(\eta^{5}-\mathrm{P}_{5}\right)\right](52 \mathrm{mg}, \quad 0.15 \mathrm{mmol})$ and ortho-carborane (10 $\mathrm{mg}$, $0.05 \mathrm{mmol})$ in toluene $(10 \mathrm{~mL})$ at room temperature. During diffusion, dark brown cubic crystals of $\mathrm{C}_{2} \mathrm{~B}_{10} \mathrm{H}_{12} @\left[\left\{\mathrm{Cp} * \mathrm{Fe}\left(\eta^{5}-\mathrm{P}_{5}\right)\right\}_{12}\{\mathrm{CuCl}]_{20}\right]^{[14]}(\mathbf{1 0})$, brown plates of $\mathbf{5}$, and very thin yellow needles of 1 were formed. The mother liquor was decanted and the obtained crystals washed with pentane and dried under vacuum (5 and 1: together $10 \mathrm{mg}$ (5: minority, only a few crystals; 1: majority: about $0.0013 \mathrm{mmol}, 11 \%$ ); 10: $4 \mathrm{mg}$, $0.0006 \mathrm{mmol}, 5.1 \%$ ).

Synthesis of $\left[\mathrm{Cp} * \mathrm{Fe}\left(\eta^{5} \cdot \mathbf{P}_{5}\right)\right] @\left[\left[\mathbf{C p} * \mathbf{F e}\left(\eta^{5}-\mathbf{P}_{5}\right)\right]_{12}[\mathrm{CuBr}]_{25} *\right.$ $\left.(\mathrm{MeCN})_{10}\right] \cdot 2.9 \mathrm{C}_{6} \mathrm{H}_{4} \mathrm{Cl}_{2} \cdot 3.9 \mathrm{MeCN}(6)$ and $\left[\mathrm{Cp} * \mathrm{Fe}\left(\eta^{5}-\mathrm{P}_{5}\right)\right] @\left[\mathrm{Cp} * \mathrm{Fe}\left(\eta^{5}\right.\right.$. $\left.\left.\left.\mathbf{P}_{5}\right)\right\}_{12}\{\mathrm{CuBr}\}_{25}(\mathrm{MeCN})_{10}\right] \cdot 2.1 \mathrm{C}_{6} \mathrm{H}_{4} \mathrm{Cl}_{2} \cdot \mathrm{MeCN}$ (7): A solution of $\mathrm{CuBr}$ (43 $\mathrm{mg}, 0.30 \mathrm{mmol})$ in a mixture of $\mathrm{CH}_{3} \mathrm{CN}(10 \mathrm{~mL})$ and ortho-dichlorobenzene $(5 \mathrm{~mL})$ was layered onto a solution of $\left[\mathrm{Cp} * \mathrm{Fe}\left(\eta^{5}-\mathrm{P}_{5}\right)\right](1)(52 \mathrm{mg}$, $0.15 \mathrm{mmol})$ in ortho-dichlorobenzene $(10 \mathrm{~mL})$ at room temperature. During slow diffusion brown plates of 6 and dark brown lath-shaped crystals of 7 were formed. After complete diffusion the mother liquor was decanted and the obtained crystals were washed with hexane and dried under vacuum (38 $\mathrm{mg}, 0.0043 \mathrm{mmol}, 37.4 \%$ ).

Synthesis of $\left[\mathrm{Cp}^{* \mathrm{Fe}}\left(\eta^{5} \cdot \mathrm{P}_{5}\right)\right] @\left[\left\{\mathrm{Cp}^{*} \mathrm{Fe}\left(\eta^{5}-\mathrm{P}_{5}\right)\right]_{12}[\mathrm{CuBr}]_{25}\right.$ $\left.(\mathrm{MeCN})_{10}\right] \cdot 10.4 \mathrm{C}_{7} \mathrm{H}_{8} \cdot 0.8 \mathrm{MeCN}(8)$ : A solution of $\mathrm{CuBr}(47 \mathrm{mg}$, $0.33 \mathrm{mmol})$ in $\mathrm{CH}_{3} \mathrm{CN}(8 \mathrm{~mL})$ was layered onto a solution of [Cp*Fe $(\eta]^{5}$ $\left.\left.P_{5}\right)\right](52 \mathrm{mg}, 0.15 \mathrm{mmol})$ and $o-C_{2} B_{10} \mathrm{H}_{12}(10 \mathrm{mg}, 0.05 \mathrm{mmol})$ in toluene $(10 \mathrm{~mL})$ at room temperature. After complete diffusion of the phases, a few brown plates of the polymeric compound $\left[\mathrm{CuBr}\left\{\mathrm{CP} \mathrm{P}^{*} \mathrm{Fe}\left(\eta^{5}: \eta^{1}: \eta^{1}: \eta^{1}\right.\right.\right.$. $\left.P_{5}\right)[]_{n}{ }^{[6]}$ and brown blocks of $\mathbf{8}$ as the major product were formed. After recrystallization from $\mathrm{CH}_{3} \mathrm{CN} /$ toluene mixtures, the obtained crystals 8 were washed with pentane and dried under vacuum $(31 \mathrm{mg}, 0.0032 \mathrm{mmol}$, $27.8 \%$ ).

Synthesis of $\left[\mathrm{Cp} * \mathrm{Fe}\left(\eta^{5}-\mathrm{P}_{5}\right)\right] @\left[\left[\mathrm{Cp} * \mathrm{Fe}\left(\eta^{5}-\mathrm{P}_{5}\right)\right]_{12}[\mathrm{CuBr}\}_{25}\right.$. $\left.(\mathrm{MeCN})_{10}\right] \cdot 5 \mathrm{C}_{7} \mathrm{H}_{8} \cdot 17.7 \mathrm{MeCN}$ (9): A solution of $\mathrm{CuBr}(25 \mathrm{mg}$, $0.174 \mathrm{mmol})$ in $\mathrm{CH}_{3} \mathrm{CN}(10 \mathrm{~mL})$ was layered onto a solution of [Cp*Fe$\left.\left(\eta^{5}-\mathrm{P}_{5}\right)\right](30 \mathrm{mg}, 0.087 \mathrm{mmol})$ and $\left[\mathrm{Cp}_{2} \mathrm{Fe}\right](28 \mathrm{mg}, 0.15 \mathrm{mmol})$ in toluene $(10 \mathrm{~mL})$ at room temperature. After complete diffusion of the phases, brown blocks of 9 had formed. The mother liquor was decanted and the obtained crystals were washed with pentane and dried under vacuum (23 $\mathrm{mg}, 0.0024 \mathrm{mmol}, 35.8 \%$ ).

Analytical data for CuCl-containing compounds 3-5: ${ }^{1} \mathrm{H}$ NMR $\left(400.132 \mathrm{MHz}, \mathrm{CD}_{2} \mathrm{Cl}_{2} / \mathrm{CD}_{3} \mathrm{CN}, 293 \mathrm{~K}\right.$ ): $\delta=2.14$ (s, Cp* ${ }_{\text {ball }}$ ), $2.24 \mathrm{ppm}$ (s, $\left.\mathrm{Cp}^{*}{ }_{\text {enc }}\right) ; ;^{[34]}{ }^{31} \mathrm{P}\left[{ }^{1} \mathrm{H}\right\} \mathrm{NMR}\left(161.975 \mathrm{MHz}, \mathrm{CD}_{2} \mathrm{Cl}_{2} / \mathrm{CH}_{3} \mathrm{CN}, 293 \mathrm{~K}\right): \delta=67$ (brs), $148.7 \mathrm{ppm}\left(\mathrm{s}_{3}\left[\mathrm{Cp} * \mathrm{Fe}\left(\eta^{5}-\mathrm{P}_{5}\right)\right]\right.$ encapsulated in compounds $\left.3-5\right) .{ }^{31} \mathrm{P}$ MAS NMR (300 MHz, $\mathrm{NaH}_{2} \mathrm{PO}_{4}$ ext.): $\delta=160.2$ (s, [Cp*Fe $\left.\left(\eta^{5}-\mathrm{P}_{5}\right)\right]$ encapsulated in compounds 1 and 2 ), $75 \mathrm{ppm}$ (very broad, consisting of overlapping resonances at $74.4,106.6,117.0$ and $131.0 \mathrm{ppm}$ ).

Analytical data for CuBr-containing compounds 6-9: ${ }^{1} \mathrm{H}$ NMR $\left(400.132 \mathrm{MHz}, \mathrm{CD}_{2} \mathrm{Cl}_{2} / \mathrm{CD}_{3} \mathrm{CN}, 293 \mathrm{~K}\right):^{[34]} \delta=2.21\left(\mathrm{~s}, \mathrm{Cp}^{*}\right.$ ball $), 2.23 \mathrm{ppm}$ (s; $\left.\mathrm{Cp}^{*}{ }_{\text {enc }}\right) ;{ }^{31} \mathrm{P}\left[{ }^{1} \mathrm{H}\right\}$ NMR $\left(161.975 \mathrm{MHz}, \mathrm{CD}_{2} \mathrm{Cl}_{2} / \mathrm{CH}_{3} \mathrm{CN}, 293 \mathrm{~K}\right): \delta=67$ (brs), $149.9 \mathrm{ppm}\left(\mathrm{s},\left[\mathrm{Cp} * \mathrm{Fe}\left(\eta^{5}-\mathrm{P}_{5}\right)\right]\right.$ encapsulated in compounds 6-9). ${ }^{31} \mathrm{P}$ MAS NMR ( $300 \mathrm{MHz}, \mathrm{NaH}_{2} \mathrm{PO}_{4}$ ext.): $\delta=74 \mathrm{ppm}$ (very broad, sometimes the broad signal shows a second peak at $\delta=116 \mathrm{ppm}$, which overlays the signal for encapsulated $\left.\left[\mathrm{Cp} * \mathrm{Fe}\left(\eta^{5}-\mathrm{P}_{5}\right)\right]\right)$.

$X$-ray studies: All crystals are unstable in air and lose solvent readily when out of the mother solution. To handle crystals mineral oil was used for isolation from air and mounting to the goniometer head under a cool nitrogen stream. The diffraction data for 3 and 4 were collected on Bruker Smart CCD and Stoe IPDS I diffractometers, respectively, with Mo $_{\mathrm{Ka}}$ radiation $(\lambda=0.71073 \AA)$. The data for $5-9$ were collected on an Oxford Diffraction Gemini R-Ultra diffractometer equipped with CCD detector and Ultra $\mathrm{Cu}_{\mathrm{Ka}}$ radiation source $(\lambda=1.54178 \AA)$ by using combined $\phi$ and $\omega$ scans of wide frames $\left(1^{\circ}\right)$. All experiments were performed at low temperature. All structures were solved by direct methods and refined by full-matrix least-squares methods against $|F|^{2}$ in anisotropic approximation by using SHELXTL ${ }^{[35]}$ or SIR2004 ${ }^{[36]}$ program sets. Absorption corrections were applied empirically for $3,{ }^{[37]} 5$, and $7,{ }^{[38]}$ and analytically for $6-9 .{ }^{[38]}$ Hydrogen atoms were refined in calculated positions. Solvent molecules in all structures are strongly disordered, and cannot all be localized owing to low diffracting power of the crystals. The encapsulated $\left[\mathrm{Cp} * \mathrm{Fe}\left(\eta^{5}-\mathrm{P}_{5}\right)\right]$ molecules are disordered over two $(3,5-9)$ 
or three (4) positions. In 6-9 they were localized in an electron-density map completely excluding $\mathrm{H}$ atoms. The occupation of each position, if unrelated by symmetry, was refined first with fixed a.d.p. parameters; occupations were found to be $0.25 / 0.25$ in $3,0.20 / 0.20 / 0.20$ in $4,0.5 / 0.5$ in 5 and $6,0.67 / 0.33$ in $7,0.78 / 0.22$ in 8 and $0.70 / 0.30$ in 9 . When only $P_{5}$ rings were localized (in $\mathbf{3}-\mathbf{5}$ and $\mathbf{8}$ ), the carbon atoms of $\left[\mathrm{Cp} * \mathrm{Fe}\left(\eta^{5}-\mathrm{P}_{5}\right)\right]$ molecules were approximated by using the OFIT command of the XP program $^{[35]}$ with the model of the molecule taken from literature data. ${ }^{[36]}$ The model was fitted by its $\mathrm{Fe}$ atom and $\mathrm{P}_{5}$ ring over those localized from the electron-density map, and then the structure was refined in usual way. A number of restraints are applied to keep normal geometric parameter for solvent and encapsulated molecules during refinement. Light atoms with occupation factors less than 0.5 were refined in isotropic approximation.

Detailed crystallographic data and selected interatomic distances are col lected in Tables 1 and 2, respectively. CCDC-744110(3), CCDC-744111 (4), CCDC-744112 (5), CCDC-744113 (6), CCDC-744114 (7), CCDC 744115 (8), and CCDC-744116 (9) contain the supplementary crystallographic data for this paper. These data can be obtained free of charge from The Cambridge Crystallographic Data Centre via www.ccdc.cam.

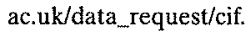

Crystal packing of $\left[\left[\mathrm{Cp} * \mathrm{Fe}\left(\eta^{3}-\mathrm{P}_{5}\right)\right\}_{12}\{\mathrm{CuX}\}_{25}(\mathrm{MeCN})_{10}\right]$ molecules, where $\mathrm{X}=\mathrm{Cl}, \mathrm{Br}$, and related structural units in 1-9 were analyzed with program package for multipurpose crystallochemical analysis $\operatorname{TOPOS}^{[39]}$ by using the same approach that is used for analysis of organic molecular compounds ${ }^{[28]}$ All quasi-spherical $\left[\left[\mathrm{Cp} * \mathrm{Fe}\left(\eta^{5}-\mathrm{P}_{5}\right)\right]_{12}[\mathrm{CuX}]_{25}(\mathrm{MeCN})_{10}\right]$ molecules $(2-4,6-9)$, ion pair $\left[\mathrm{Cu}(\mathrm{MeCN})_{4}\right]^{+}\left[I \mathrm{Cp} * \mathrm{Fe}\left(\eta^{5}-\mathrm{P}_{5}\right)\right\}_{12} \mathrm{Cu}_{24} \mathrm{Cl}_{25}$ $\left.(\mathrm{MeCN})_{8}\right]^{-}(\mathbf{1 b})$, and each spherical moiety $\left[\left[\mathrm{Cp} * \mathrm{Fe}\left(\eta^{5}-\mathrm{P}_{5}\right)\right] \mathrm{Cu}_{25} \mathrm{Cl}_{24}\right.$ $\left.(\mathrm{MeCN})_{9}\right]^{+}$and $\left[\left[\mathrm{Cp}^{*} \mathrm{Fe}\left(\eta^{5}-\mathrm{P}_{5}\right)\right] \mathrm{Cu}_{25} \mathrm{Cl}_{26}(\mathrm{MeCN})_{9}\right]^{-}$(5) were approximated by pseudo-atoms located at their centres of gravity. Solvent molecules were omitted because of their disorder. Furthermore, Voronoi-Dirichle polyhedra ${ }^{[00]}$ were constructed around the pseudo-atoms to find contacts between pseudo-atoms in the crystal and to construct the packing graph. ${ }^{[41]}$ The net of centroids (centres of gravity) of the spherical was created in a similar way, but the net edges between the centroids exist only if there are van der Waals contacts between the units; all contacts shorter than the sum of van der Waals radii ${ }^{[20]}$ of interacting atoms were taken into account. In contrast to the packing graph, which characterizes the spatial arrangement of even disconnected objects, the net of centroids describes the topology of somehow connected molecular moieties. The topology of the packing graph and the net of centroids is described by coordination sequences, ${ }^{[42]}$ which allow determination of the corresponding topological motif (Table 3 ).

Electrochemical investigations: All electrochemical experiments were performed in a home-built cylindrical vacuum-tight one-compartment cell. A spiral Pt wire and a Ag wire as the counter- and reference electrodes are sealed directly into opposite sides of the glass wall while the respective working electrode (platinum or glassy carbon 1.1 or $1.6 \mathrm{~mm}$ diameter, Pt $50 \mu \mathrm{m}$ or Au $60 \mu \mathrm{m}$ for linear sweep voltammetry), polished with $0.25 \mu \mathrm{m}$ diamond paste (Buehler-Wirtz) before each experiment), is introduced through a Teflon screw cap with a suitable fitting. The cell can be attached to a conventional Schlenk line via two side arms equipped with Teflon screw valves and allows experiments to be performed under an atmosphere of argon with approximately $2.5 \mathrm{~mL}$ of ana lyte solution. The solvents were obtained in the highest available purity from commercial sources $\left(\mathrm{CH}_{2} \mathrm{Cl}_{2}\right.$ from Fluka (Burdick\&Jackson Brand) $\mathrm{CH}_{3} \mathrm{CN}$ (HPLC Gradient Grade) from Roth and freshly distilled from $\mathrm{CaH}_{2}$ before use. $\mathrm{NBu}_{4} \mathrm{PF}_{6}(0.25 \mathrm{~mm})$ was used as the supporting electrolyte. All potentials are referenced versus the ferrocene/ferrocenium couple. The electrolysis cell is a home-built three-compartment cell. The central port contains a $\mathrm{Pt}$ basket directly sealed into the sidewall as a working electrode. A smaller Pt basket is used as counterelectrode and an $\mathrm{Ag}$ rod as pseudo-reference electrode. The individual compartments are separated by a fine frit. The cell can be attached to a vacuum line via a sidearm. Every compartment can be closed with a glass stopper. A microdisc electrode for obtaining voltammetric scans before or after bulk electrolysis is introduced into the central compartment through an appropriate screw cap. Electrochemical data are acquired with a computer -controlled EG\&G model 273 potentiostat utilizing the EG\&G 250 software package. The ESR equipment consists of a Bruker ESP $3000 \mathrm{spec}$ trometer equipped with a HP frequency counter $5350 \mathrm{~B}$, a Bruker NMR gaussmeter ER 035M and a continuous-flow cryostat ESR 900 from Oxford Instruments for low-temperature work. For chronoamperometry and the Baranski method, $1\left(2.00 \mathrm{mg}_{2} 2.543 \times 10^{-7} \mathrm{~mol}\right)$ and $\mathrm{NBu}_{4} \mathrm{PF}_{6}$ $(120 \mathrm{mg})$ were dissolved in $\mathrm{CH}_{3} \mathrm{CN}: \mathrm{CH}_{2} \mathrm{Cl}_{2}(1: 3)(3.0 \mathrm{~mL})$. For reduction, the potential was stepped from $-0.9 \mathrm{~V}$ to $-1.3 \mathrm{~V}$ and held for $4 \mathrm{~s}$, during which interval the current was recorded as a function of time. Plotting the function $i t^{1 / 2}$ versus time identified the domain in which the Cottrell equation (predicting a constant value of this function) is fulfilled (at short times the current assumes very high values resulting in overdrive of the recording device). For the respective domain the slope of the function $i(t)$ versus $t^{-1 / 2}$ was determined. The average value of three independent measurements was used in the calculations. Steady-state voltammograms were recorded on a gold microelectrode with a diameter of $60 \mu \mathrm{m}$ at a sweep rate of $5 \mathrm{mVs}^{-1}$. As the standard for the Baranski method, a solution of $\left[\mathrm{Cp}_{2}^{*} \mathrm{Fe}\right]\left(1.94 \mathrm{mg}, 5.95 \times 10^{-6} \mathrm{~mol}\right)$ in the same supporting electrolyte system $(3.6 \mathrm{~mL})$ and the same electrodes as above were used. The surface area of the electrode used in the chronoamperometry experiment $\left(0.075 \mathrm{~cm}^{2}\right.$, glassy carbon (BAS), nominal diameter $3 \mathrm{~mm}$ ) was determined by chronoamperometry with ferrocene standard according to the procedure given by Kochi et al. ${ }^{[4.3]}$ The diffusion coefficients of 1 and 2 were determined as $7.0( \pm 0.8) \cdot 10^{7} \mathrm{~cm}^{2} \mathrm{~s}^{-1}$ and 5.0 $( \pm 0.7) \cdot 10^{7} \mathrm{~cm}^{2} \mathrm{~s}^{-1}$, respectively, that is, ca. $2-3 \%$ of the value of $[\mathrm{Cp} * \mathrm{Fe}-$ $\left.\left(\eta^{5}-P_{5}\right)\right]$.

DFT calculations: All calculations are performed with the TURBOMOLE program package ${ }^{[44,45]}$ We employed the DFT method with the BP86 exchange-correlation functional. ${ }^{[46]}$ To speed up the calculations the Coulomb part was evaluated by using the MARI-J method: ${ }^{[47]}$ For structure optimization SV(P) ${ }^{[48]}$ and TZVP basis ${ }^{[49]}$ and auxiliary basis ${ }^{[50]}$ on all atoms were used. Calculations of ${ }^{31} \mathrm{P}$ chemical shifts by the GIAO approach ${ }^{[51]}$ used a TZP basis set on $\mathrm{P}$ and TZVP on all other atoms. ${ }^{[52]}$ The ${ }^{31} \mathrm{P}$ chemical shifts relative to $85 \% \mathrm{H}_{3} \mathrm{PO}_{4}$ were calculated by using OP$\left(\mathrm{CH}_{3}\right)_{3}$ as an internal secondary standard with an experimental ${ }^{31} \mathrm{P}$ chemical shift of $140 \mathrm{ppm}$ relative to $85 \% \mathrm{H}_{3} \mathrm{PO}_{4}{ }^{[53]}$ DFT calculations on anions used the conductor-like screening model (COSMO) approach. ${ }^{[54]}$

\section{Acknowledgements}

This work was comprehensively supported by the Deutsche Forschungsgemeinschaft and the Fonds der Chemischen Industrie. The authors are grateful to Dr. C. Anson [Universität Karlsruhe (TH)] and Dr. M. Zabel for measuring $X$-ray data for 3 and 4 .

[1] a) J.M. Lehn, Supramolecular Chemistry: Concepts and Perspectives, VCH, Weinheim, 1995; b) R. W. Saalfrank, B. Demleitner in Transition Metals in Supramolecular Chemistry, Vol. 5 (Ed.; J.-P. Sauvage), Wiley-VCH, Weinheim, 1999, pp.1-51; c) M. M. Conn, J. Rebek, Jr., Chem. Rev. 1997, 97, 1647-1668; d) C. J. Jones, Chem. Soc. Rev. 1998, 27, 289-299; e) G. F. Swiegers, T. J. Malefetse, Chem. Rev. 2000, 100, 3483-3537; f) S. Leininger, B. Olenyuk, P. J. Stang, Chem. Rev. 2000, 100, 853-908; g) M. Fujita, M. Tominaga, A. Hori, B. Therrien, Acc. Chem. Res. 2005, 38, 369-378; h) T. Kreickmann, F. E. Hahn, Chem. Commun. 2007, 1111-1120.

[2] a) H.-G. Schnöckel, H. Köhnlein, Polyhedron 2002, 21, 489-502; b) H.-G. Schnöckel, A. Schnepf, Angew. Chem. 2002, 114, 36823704; Angew. Chem. Int. Ed. 2002, 41, 3532-3554; c) J. Hartig, A. Schnepf, L. Jos de Jongh, D. Bonob, H.-G. Schnöckel, Z. Anorg. Allg. Chem. 2007, 633, 63-76; d) M. Huber, A. Schnepf, C. E Anson, H.-G. Schnöckel, Angew. Chem. 2008, 120, 8323-8328; Angew. Chem. Int. Ed. 2008, 47, 8201-8206; e) H.-G. Schnöckel, Dalion Trans. 2008, 4344-4362.

[3] a) S. Dehnen, A. Eichhöfer, J. F. Corrigan, D. Fenske in Synthesis and Characterization of $I b-I V$ Nanoclusters: Nanoparticles (Ed.: G. 
Schmid), Wiley-VCH, Weinheim 2003; b) D. Fenske, C. Persau, S Dehnen, C. E. Anson, Angew. Chem. 2004, 116, 309-313; Angew. Chem. Int. Ed. 2004, 43, 305-309; c) D. Fenske, C. E. Anson, A Eichhöfer, O. Fuhr, A. Ingendoh, C. Persau, C. Richert, Angew. Chem. 2005, 117, 5376-5381; Angew. Chem. Int. Ed. 2005, 44, 52425246; d) C. E. Anson, A. Eichhöfer, I. Issac, D. Fenske, O. Fuhr, P Sevillano, C. Persau, D. Stalke, J. Zhang, Angew. Chem. 2008, 120 1346-1351; Angew. Chem. Int. Ed. 2008, 47, 1326-1331.

[4] a) L. Cronin, E. Diemann, A. Müller in Inorganic Experiments (Ed.: J. D. Woollins), Wiley-VCH, Weinheim, 2003, pp. 340-346; b) A Müller, S. Roy in The Chemistry of Nanomaterials: Synthesis Properties and Applications, Vol. $I I$ (Eds.: C. N. R. Rao, A. Müller, A. K. Cheetham), Wiley-VCH, Weinheim, 2004, pp.452-475; c) A. Müller, E. Krickemeyer, H. Bögge, M. Schmidtmam, F. Peters Angew. Chem. 1998, 110, 3567-3571; Angew. Chem. Int. Ed. 1998, 37, 3359-3363; d) A. Müller, E. Krickemeyer, H. Bögge, M Schmidtmann, S. Roy, A. Berkle, Angew. Chem. 2002, 114, 3756 3761; Angew. Chem. Int. Ed. 2002, 41, 3604-3609; e) A. Müller, P Kögerler, C. Kuhlmann, Chem. Commun. 1999, 1347-1358; f) T. Mitra, P. Miró, A.-R. Tomsa, A. Merca, H. Bögge, J. B. Avalos, J. M Poblet, C. Bo, A. Müller, Chem. Eur. J. 2009, 15, 1844-1852; g) C Schäffer, A. Merca, H. Bögge, A. M. Todea, M. L. Kistler, T. Liu, R. Thouvenot, P. Gouzerh, A. Müller, Angew. Chem. 2009, 121, 155159; Angew. Chem. Int. Ed. 2009, 48, 149-153.

[5] For a recent review, see: M. Scheer, Dalton Trans. 2008, 4372-4386 for a 32-vertex ball, see: B. P. Johnson, F. Dielmann, G. Balázs, M. Sierka, M. Scheer, Angew. Chem. 2006, 118, 2533-2536; Angew. Chem. Int. Ed. 2006, 45, 2473-2475.

[6] a) J. Bai, E. Leiner, M. Scheer, Angew. Chem. 2002, 114, 820-823; Angew. Chem. Int. Ed. 2002, 41,783-786; b) J. Bai, A. V. Virovets, M. Scheer, Angew. Chem. 2002, 114, 1808-1811; Angew. Chem. Int. Ed. 2002, 41, 1737-1740; c) S. Welsch, L. J. Gregoriades, M. Sierka, M. Zabel, A. Virovets, M. Scheer, Angew. Chem. 2007, 119, 94839487; Angew. Chem. Int. Ed. 2007, 46, 9323-9326.

[7] a) J. Bai, A. V. Virovets, M. Scheer, Science 2003, 300, 781-783; b) M. Scheer, J. Bai, B. P. Johnson, R. Merkle, A. V. Virovets, C. E. Anson, Eur. I. Inorg. Chem. 2005, 4023-4026; c) M. Scheer, L. J. Gregoriades, R. Merkle, B. P. Johnson, F. Dielmann, Phosphorus, Sulfur Silicon Relat. Elem. 2008, 183, 504-508.

[8] Concentrations discussed here refer to the overall concentrations of complexes $\left[\mathrm{Cp} * \mathrm{Fe}\left(\eta^{5}-\mathrm{P}_{5}\right)\right]$, as calculated from the total volume obtained after layering with the $\mathrm{CuX}$ solutions.

[9] Note that encapsulated $\left[\mathrm{Cp} * \mathrm{Fe}\left(\eta^{5}-\mathrm{P}_{5}\right)\right]$ was first found in 1 . However, it was only mentioned in the Supporting Information ${ }^{[7 a]}$ as well as in the submitted CIF file.

[10] The crystals of obtained 1 can be formulated as $(\mathbf{1 a})_{3}(\mathbf{1} \mathbf{b})$, which describes the existence of three molecules of $1 \mathrm{a}$ and one molecule of $\mathbf{1 b}$ in the unit cell.

[11] V. A. Blatov, M. O'Keeffe, D. M. Proserpio, Cryst. Eng. Comm. 2010, 12, 44-48

[12] Note that the description above is purely combinatorial, not chemical. We have no NMR, MS or X-ray structural evidence for the formation of shells as one of the stages of chemical reaction resulting in 90 - or 80 -vertex moieties. This description helps to understand the relation between 80 - and 90 -vertex molecules and the origin of pseudo-fivefold symmetry.

[13] P. Drevensek, T. Zupancic, B. Pihlar, R. Jerala, U. Kolitsch, A. Plaper, I. Turel, J. Inorg. Biochem. 2005, 99, 432 442 .

[14] a) M. Scheer, A. Schindler, C. Gröger, A. V. Virovets, E. V. Peresypkina, Angew. Chem. 2009, 121, 5148-5151; Angew. Chem. Int. Ed. 2009, 48,5046-5049; for an encapsulated $C_{60}$ sphere, see: $M$ Scheer, A. Schindler, R. Merkle, B. P. Johnson, M. Linseis, R. Winter, C. E. Anson, A. Virovets, J. Am. Chem. Soc. 2007, 129, 13386-13387.

[15] Database of Zeolite Structures, http:/wwwiza-structure.org/ databases/.

[16] F. H. Allen, Acta Crystallogr. Sect. B 2002, 58, 380-388.
[17] M. Scheer, L. J. Gregoriades, A. V. Virovets, W. Kunz, R. Neueder, I. Krossing, Angew. Chem. 2006, 118, 5818-5822; Angew. Chem. Int Ed. 2006, 45, 5689-5693.

[18] F. Dielmann, R. Merkle, S. Heinl, M. Scheer, Z. Naturforsch. B $2009,64,3-10$.

[19] Note that the outer radius of compound 2 is even larger due to the presence of $\mathrm{Cp}^{\mathrm{Et}}$ ligands (Table $1 \mathrm{~S}$ in the Supporting Information) and thus is not discussed for reasons of incomparability.

[20] A. Bondi, J. Phys. Chem. 1964, 68, 441-451.

[21] B. Rink. O. J. Scherer, G. Wolmershäuser, Chem. Ber. 1995, I28, $71-$ 73.

[22] a) P. de Hoog, P. Gamez, I. Mutikainen, U. Turpeinen, J. Reedijk, Angew. Chem. 2004, 116, 5939-5941; Angew. Chem. Int. Ed. 2004, 43, 5815-5817; b) A. N. M. M. Rahman, R. Bishop, D. C. Craig, M. L. Scudder, Org. Biomol. Chem. 2004, 2, 175-182; c) S. Demeshko, S. Dechert, F. Meyer, J. Am. Chem. Soc. 2004, 126, 4508-4509.

[23] C. Janiak, J. Chem. Soc. Dalton Trans. 2000, 3885-3896.

[24] A. F. Wells, Structural Inorganic Chemistry, 5th ed., Clarendon, Oxford, 1984.

[25] J. H. Conway, N. J. A. Sloane, Sphere Packings, Lattices and Groups, Springer, New York, 1988, p. 663.

[26] See contribution to "unsolved problems in mathematics": T. C. Hales, Ann. Math. Stat. 2005, 162, 1065-1185.

[27] A. I. Kitaigorodskii, Organic Chemical Crystallography, Consultants Bureau, New York, 1961.

[28] E. V. Peresypkina, V. A. Blatov, Acta Crystallogr. 2000, 56, 1035 1045.

[29] E. V. Peresypkina, V. A. Blatov, Z. Kristallogr. 2002, 217, 91-102.

[30] N. W. Ockwig, O. Delgado-Friedrichs, M. O'Keeffe, O. M. Yaghi, Acc. Chem. Res. 2005, 38, 176-182.

[31] A. S. Baranski, W. R. Fawcett, C. M. Gilbert, Anal. Chem. 1985, 57, $166-170$.

[32] R. F. Winter, W. E. Geiger, Organometallics 1999, 18, 1827-1833.

[33] M. Detzel, G. Friedrich, O. J. Scherer, G. Wolmershäuser, Angew. Chem. 1995, 107, 1454; Angew. Chem. Int. Ed. Engl. 1995, 34, 1321.

[34] The $\mathrm{CH}_{3} \mathrm{CN}$ protons are interfered with by those of $\mathrm{CD}_{3} \mathrm{CN}$

[35] SHELXTL, Version 6.22, 2003, Bruker AXS Inc. Madison.

[36] M. C. Burla, R. Caliandro, M. Camalli, B. Carrozzini, G. L. Cascarano, L. De Caro, C. Giacovazzo, G. Polidoria, J. Appl. Crystallogr. 2005, 38, $381-388$.

[37] SADABS, Program for empirical X-ray absorption correction, G. M. Sheldrick, Bruker-Nonius, 1990.

[38] SCALE3 ABSPACK scaling algorithm. CrysAlis RED, Version 1.171.31.8, Oxford Diffraction Lid. Oxfordshire.

[39] V. A. Blatov, Cryst. Comp. Newsletter 2006, 7, 4-38 (http://www. iucr.org/iucr-top/comm/ccom/newsletters/).

[40] V. A. Blatov, Crystallogr. Rev. 2004, 10, 249-318.

[41] V. A. Blatov, Acta Crystallogr. Sect. A 2000, 56, 178-188.

[42] M. O'Keeffe, Z. Kristallogr. 1995, 210, 135-140.

[43] J. W. Hershberger, R. J. Klingler, J. K. Kochi, J. Am. Chem. Soc. $1983,105,61-73$.

[44] TURBOMOLE V6.0 2009, a development of University of Karlsruhe and Forschungszentrum Karlsruhe GmbH, 1989-2007, TURBOMOLE GmbH, since 2007; available from http://www.turbomole. com.

[45] a) R. Ahlrichs, M. Bär, M. Häser, H. Horn, C. Kölmel, Chem. Phys. Lett. 1989, 162, 165-169; b) O. Treutler, R. Ahlrichs, J. Chem. Phys. $1995,102,346-354$

[46] a) A. D. Becke, Phys. Rev. A 1988, 38, 3098-3100; b) S. H. Vosko, L. Wilk, M. Nusair, Can. J. Phys. 1980, 58, 1200-1211; c) J. P. Perdew, Phys. Rev. B 1986, 33, 8822-8824; Erratum: J. P. Perdew, Phys. Rev. B 1986, 34, 7406 .

[47] M. Sierka, A. Hogekamp, R. Ahlrichs, J. Chem. Phys. 2003, 118, 9136-9148.

[48] A. Schäfer, H. Horn, R. Ahlrichs, J. Chem. Phys. 1992, 97, $2571-$ 2577.

[49] A. Schäfer, C. Huber, R. Ahlrichs, J. Chem. Phys. 1994, 100, 58295835. 
[50] a) K. Eichkorn, O. Treutler, H. Ohm, M. Häser, R. Ahlrichs, Chem. Phys. Lett. 1995, 242, 652-660; b) K. Eichkorn, F. Weigend, O. Treutler, R. Ahlrichs, Theor. Chem. Acc. 1997, 97, 119-124.

[51] G. Schreckenbach, T. Ziegler, J. Phys. Chem. 1995, 99, 606-611.

[52] a) A. Schäfer, H. Horn. R. Ahlrichs, J. Chem. Phys. 1992, 97, 2571 2577; b) A. Schäfer, C. Huber. R. Ahlrichs, J. Chem. Phys. 1994 $100,5829-5835$

[53] D. G. Gorenski, Phosphorus-31 NMR, Principles and Applications, Academic Press, New York, 1984
[54] A. Klamt, G. Schüürmann, J. Chem. Soc. Perkin Trans. 1 1993, 2, $799-805$.

[55] G. O. Brunner, F. Laves, Wiss. Z. Tech. Hochsch. Dresden 1971, 20 387-390.

[56] Reticular Chemistry Structure Resource, http://rcsr.anu.edu.au/. 